\title{
SEM-based automated mineralogy (SEM-AM) and unsupervised machine learning studying the textural setting and elemental association of gold in the Rajapalot Au-Co area, northern Finland
}

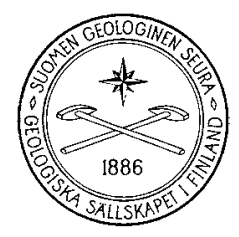

VERTAISARVIOITU KOLLEGIALT GRANSKAD PEER-REVIEWED

\author{
Jukka-Pekka Ranta ${ }^{\mathrm{I}^{*}}$, Nick Cook $^{2}$ and Sabine Gilbricht ${ }^{3}$ \\ ${ }^{1}$ Oulu Mining School, University of Oulu, P.O.Box 3000, FI-90014, Finland \\ ${ }^{2}$ Mawson Gold Ltd., BC, Canada \\ ${ }^{3} T U$-Bergakademia Freiberg, Akademiestraße 6, 09599 Freiberg, Germany
}

\begin{abstract}
SEM-based automated mineralogy (SEM-AM) techniques allow fast and effective way of studying the textural settings of gold in hydrothermal deposits. Unsupervised machine learning (e.g. self-organizing maps) is an intuitive way of processing multi-dimensional geochemical datasets in order to reveal hidden patterns potentially represent different mineralization stages. We combined these two methods for studying the relationship of gold and cobalt within different prospects in a Paleoproterozoic gold-cobalt mineralized area known as Rajapalot. Gold is found as a texturally late phase, occurring in fractures of silicates and sulfides. Based on the elemental associations observed from the whole-rock geochemical dataset using self-organizing-maps, Co-only, Au-Co and Au associations can be inferred relating to either different mineralization stages or different fluid-host rock interactions. Also, the dominant mineralization-related alteration in different occurrences within the Rajapalot Au-Co prospects are reflected as elemental associations with gold in the geochemical data. Our study shows the effectiveness SEM-AM methods for studying distribution of valuable minerals. Unsupervised neural networks provide for easy and intuitive processing technique that can be validated with the mineralogical observations.
\end{abstract}

Keywords: Gold, Cobalt, SEM-AM, Machine learning, Peräpohja belt, Finland, Paleoproterozoic

*Corresponding author (e-mail: jukka-pekka.ranta@oulu.fi)

Editorial handling: Niina Kuosmanen (e-mail: kuosmanen.niina@gmail.com) 


\section{Introduction}

Semi-automated/automated methods for studying the mineralogy and structures of the rocks and ore concentrates have gained popularity during last decade (e.g. Goodall et al. 2005; Keulen et al. 2019). A recent special issue related to the SEM-based automated mineralogy (SEM-AM) summarizes the current developments within this field (see e.g. Schulz 2020). SEM-AM allows efficient way for studying microstructures of rocks, modal mineralogy and textural setting/association for different mineral phases. In particular, studying gold-bearing hydrothermal mineral deposits allows SEM-AM methods to identify the range of textural settings of gold in mineralized systems which commonly show multi-stage evolution (e.g. Sayab et al. 2016; Molnár et al. 2016, 2018). In addition, the knowledge of the distribution of potential ore minerals are one of the key first steps when planning the mineral processing workflow. The multidimensional geochemical datasets are nearly always gathered during the mineral exploration projects. These complex geochemical databases reflect the evolution of the rocks, including the protolith and subsequent processes, for example, those related to the mineralization process. In order to efficiently analyse and visualize the information, the dimensionality of the data need to be lowered.
Statistical methods, such as correlation coefficients and principal component analyses have been widely and successfully used in the studies of hydrothermal deposits (e.g. Vasilopoulos et al. 2021). In addition to these more traditional statistical tools, different types of machine learning methods, both supervised and unsupervised are effective methods for studying the geochemical data. In the supervised learning, computer is trained with the known data to predict the unknown variables based on the information available and is used for example in optimizing the resource modelling (Jafrasteh et al. 2018; Kaplan \& Topal 2020). In unsupervised learning, algorithms search patterns from multidimensional datasets, reducing dimensionality by clustering the variables, and in the case of rock elemental concentration variables, detect associations and patterns from the geochemical multivariate data. In this study, we use SEM-AM for analysing textural setting of gold from Paleoproterozoic Au-Co resources within Rajapalot project area, in the northern part of the Peräpohja belt, northern Finland (Fig. 1 and Fig. 2a). In addition, we use self-organizing-maps (SOM), an unsupervised learning algorithm to study the whole-rock geochemical dataset from these deposits in order to investigate potential multi-mineralized events. In assessing both of these algorithm-derived datasets, we discuss and evaluate their results.

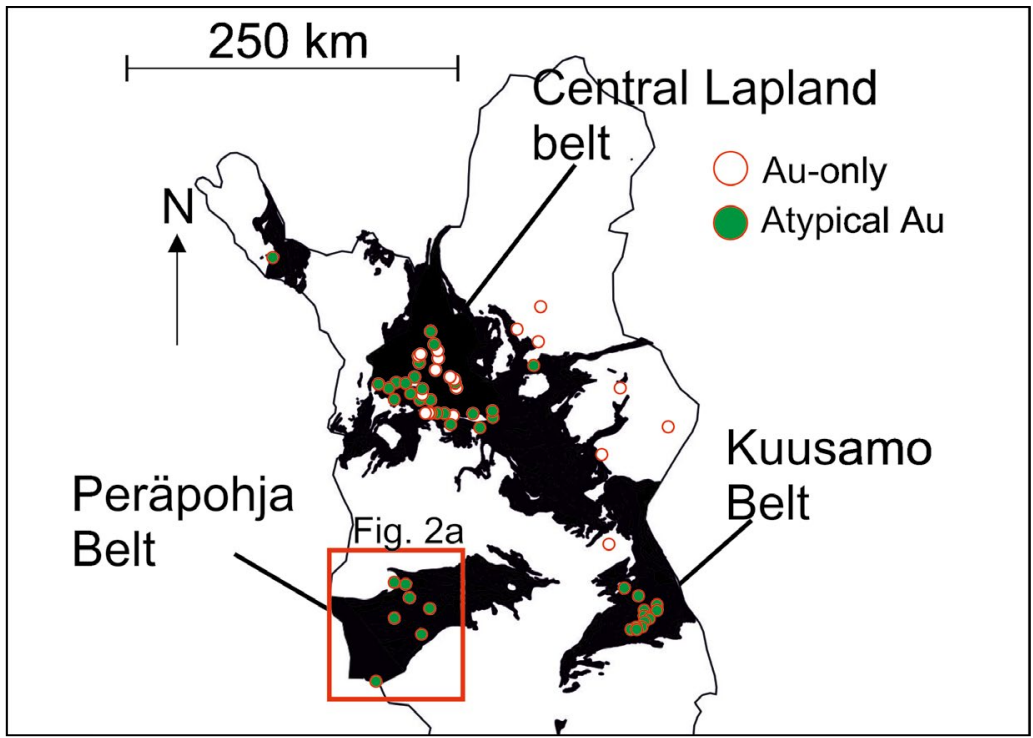

Figure 1. Simplified geological map of northern Finland. Paleoproterozoic supracrustal belts are shown in black. White and green circles with red outlines indicate Au-only and atypical Au deposits, respectively. (Deposit data collected from Bedrock of Finland [electronic resource], Geological Survey of Finland; referred on 30.3.2021). Atypical Au terminology refers to gold deposits with anomalous metal associations (e.g. Co, Cu; see Eilu 2015; Molnár 2019) 


\section{Geological background}

The Peräpohja belt belongs to the Karelian volcanosedimentary sequences deposited on rifting Archean basement between ca. $2.44 \mathrm{Ga}$ and $1.88 \mathrm{Ga}$ (e.g. Köykkä et al. 2019; Fig. 1). The age limits are based on the dating of underlying mafic layered intrusions and the monzonites of the Haaparanta series, cutting the youngest sedimentary rocks of the basin (Huhma et al. 1990; Perttunen \& Vaasjoki 2001; Iljina \& Hanski 2005). The supracrustal sequence is bounded by the Central Lapland granitoid complex in the north and east and the Archean Pudasjärvi complex in the south. Peräpohja belt is separated from the Norbotten craton in west by the N-S- trending Pajala shear zone (e.g. Lahtinen et al. 2015). Traditional division of the Peräpohja belt was established by Perttunen et al. (1995) who divided the stratigraphy into two major lithostratigraphical groups, Kivalo and Paakkola groups which are correlative to the Jatulian and Kalevian systems (Hanski \& Melezhik 2012) and record the evolution of the rifting comprising of mature siliclastics, carbonate rocks, subaerial mafic volcanic rocks and deep-water turbiditic rocks at the late stages of the rifting. The basin evolution stages are divided into 1) initial rifting/ early syn-rift, 2) syn-rift, 3) syn-rift to early postrift, 4) passive margin (post-rift), and 5) foreland system (Köykkä et al. 2019). Kivalo and Paakkola groups were further divided into eleven formations. Kyläkoski et al. (2012) introduced new formation into the stratigraphy which they inferred as a unit of evaporitic in origin (Petäjäskoski formation). Lahtinen et al. (2015, 2019) and Köykkä et al. (2019) separated the Paakkola group from the Peräpohja belt sensu stricto and assigned the rocks into several lithodemic units due to the complex structural evolution which precluded assigning the rocks into the lithostratigraphic classification. The most recent stratigraphic column is shown in the Fig. 2b.
The basin inversion was initiated during the composite Svecofennian-Kola orogenies between ca. 1.92-1.75 Ga when rocks underwent greenschist to amphibolite facies metamorphism and experienced complex brittle-ductile thrusting and folding evolution. Piippo et al. (2019) suggested development of strike-slip faults during active rifting and pull-apart basin development and highlighted the underlying Archean basement topography and its architecture (e.g., basement faults) controlling the structures of the overlying volcano-sedimentary cover during deformation.

Lahtinen et al. (2015) proposed five deformation stages from the youngest metasedimentary formation of the Peräpohja belt (the Martimo suite). D1 $(\leq 1.91 \mathrm{Ga})$ generated a NS-trending $S 1$ fabric and recumbent folds due to east-directed thin-skinned thrusting. NS-directed shortening in stage D2 (1.90-1.89 Ga) produced EW-trending folds and a pervasive, steeply dipping foliation. D3 $(1.88-1.87 \mathrm{Ga})$ is represented by NNW- and WNW-trending, heterogeneously developed structural trends. Traces of the D4 deformation $(1.83-1.81 \mathrm{Ga})$ are seen as NNE-trending lineaments in aeromagnetic images. D5 (1.79-1.77 Ga) is characterized by WSW-ENE oriented shortening.

At least four episodes of felsic to intermediate magmatism have been recognized starting from preorogenic and continuing to late- to post orogenic times: (1) the 1.99-2.0 Ga strongly flattened gneissic porphyritic Kierovaara granite (the Kierovaara granite suite; Ranta et al. 2015; Lahtinen et al. 2019), (2) the ca. 1.88 Ga synorogenic Haaparanta suite granitoids, found especially in the eastern part of the belt (Perttunen \& Vaasjoki 2001), (3) the ca. $1.80 \mathrm{Ga}$ appinitic plutons (Tainio 2014), and (4) the 1.79-1.77 Ga late-orogenic granitoids (e.g. Ranta et al. 2015). 


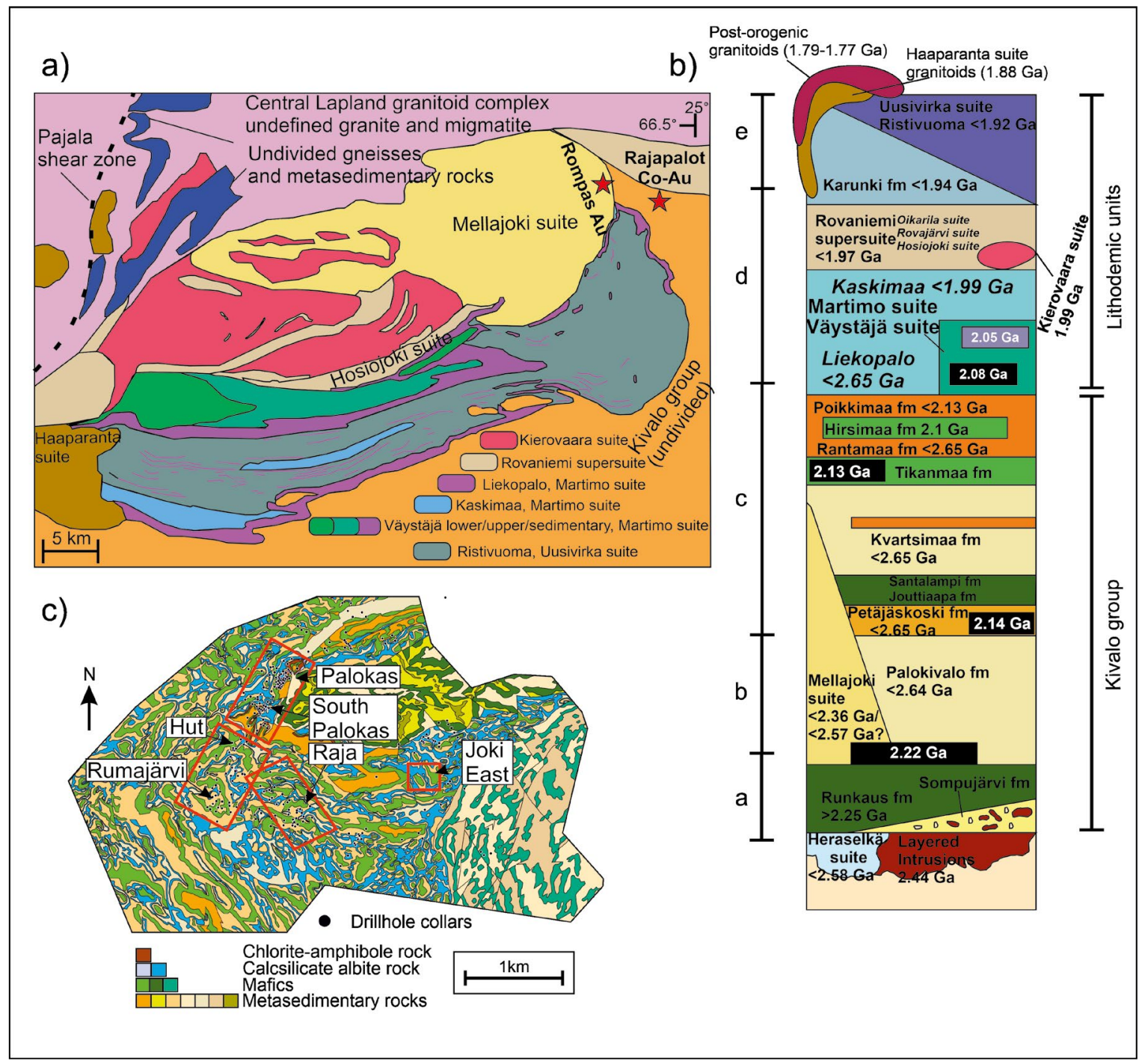

Figure 2. Geological maps and stratigraphy of the Peräpohja belt. a) Simplified regional geologic map of the Peräpohja belt modified after Ranta et al. (2020) and Lahtinen et al. 2019). b) Stratigraphic column of the Peräpohja belt modified after Köykkä et al. (2019) and references therein. Basin evolution stages (a-e) as follows: a) Initial rifting/early syn-rift, b) syn-rift, c) syn-rift to early post-rift, d) passive margin (post-rift), and e) foreland system. c) Lithogeochemical interpretation of the Rajapalot area based on the aeromagnetic data modified from map produced by Laurent Ailleres of PNG consulting (Mawson Oy unpublished report).

\section{Rompas and Rajapalot Au-Co-(U)}

The Rompas-Rajapalot Au-Co-(U) exploration area covers approximately $100 \mathrm{~km}^{2}$ of prospective ground, initially discovered in 2008 (Rompas AuU; Fig. 2a) and further discoveries in Rajapalot (AuCo) expanded the mineralized area in 2012 (Fig. 2a; see Vanhanen et al. 2015). The Rajapalot area has been subdivided into several prospects, primarily Palokas, Raja, Rumajärvi and The Hut with other smaller ones under exploration (Fig. 2c). In addition to the active exploration campaign across Rompas-Rajapalot, there are several academic studies dealing with geological evolution, oreforming processes and geochronology (e.g. Molnar et al. 2016, 2017; Ranta et al. 2017, 2018). 


\subsection{Rompas}

The Rompas Au system is hosted by mafic metavolcanic rocks with high-grade uraninitegold pockets occurring within deformed calcsilicate carbonate veins. Based on the $\mathrm{Pb}-\mathrm{Pb}$ dating of uraninite and Re-Os dating of molybdenite, primary uranium mineralization was formed during the active rifting of the basin between ca. 2050 and $2000 \mathrm{Ma}$ (Molnár et al. 2016, 2017). The ages of the primary mineralization correlate with the pre-orogenic granitoid magmatism in the area at ca. $2 \mathrm{Ga}$ (Ranta et al. 2015) and with the Re-Os age of molybdenite from the granite hosted Kivilompolo Mo-occurrence, close to the Rompas-Rajapalot area (Ranta et al. 2020). The primary uranium mineralization was re-mobilized and concentrated into the calc-silicate-carbonate veins as coarse-grained porphyroblasts at Rompas during the regional metamorphism starting from the onset of Svecofennian orogeny at ca. 1.92 Ga. The relationship between uraninite and gold is spatial but not temporal. Based on the textural relationship of gold and uraninite and detailed geochronology, Molnár et al. (2016) proposed that gold was introduced late into the system. Reaction between the uraninite and pyrobitumen associated with the uranium acted as strong reducing trap for the gold-bearing hydrothermal fluids, leading to the precipitation of gold into the fractures of uraninite or adjacent to it.

\subsection{Rajapalot}

The Rajapalot area, some 8 kilometres to the east of Rompas lacks nuggetty style high-grade uraninitegold pockets (Fig. 2a). In its place is sulfide-dominated and disseminated mineralization. The area is comprised of metavolcanic and metasedimentary rocks displaying variable alteration assemblages. The most widespread alteration is albitization, covering regionally vast areas. Two main mineralization related alteration styles are identified from the Rajapalot area, 1) Fe- $\mathrm{Mg}$ alteration and 2) $\mathrm{Fe}-\mathrm{K}$ alteration. Fe-Mg alteration is the dominant style in the Palokas occurrence, characterized by intense chloritization, sulfidation, tourmaline and magnetite. The dominant host rock for gold is an altered quartz and Ca-poor inferred metasedimentary rock with main mineralogy (excluding the alteration) comprised of albite, cordierite and anthophyllite. The cordierite-anthophyllite rocks are interlayered with albite-calcsilicate rocks and mafic metavolcanic rocks. The Fe-K alteration is characterized by the presence of finegrained phengitic white mica associated with the gold rich intervals. Tourmaline is also common adjacent to Fe-K altered rocks. Ranta et al. (2018) proposed possible association of evaporitic environments for the cordierite-anthophyllite rocks and albite-calcsilicate rocks. The presence of evaporites are supported by anhydrite- and gypsum-bearing rocks encountered during the drilling (Cook et al. 2019). Tourmaline is common and abundant mineral in the mineralized intervals related to the $\mathrm{Fe}-\mathrm{Mg}$ alteration, locally forming tourmalinites and tourmaline-sulfide breccias. Similar to Rompas, gold seems to be introduced late into the system based on the retrograde style alteration and early studies of textures of gold, correlative B-isotope values of tourmaline associated with gold and tourmaline in the $1.78 \mathrm{Ga}$ tourmaline granite (Ranta et al. 2017), and the $1.78 \mathrm{Ga}$ Re-Os age of the molybdenite associated with the gold (Molnár et al. 2017). Based on the observation of textural setting of gold in Palokas, Ranta et al. (2018) showed that gold is found in different textural locations, 1) single grains within the rock-forming silicates and 2) fracture related within chloritized host rocks and in tourmalinesulfide breccias. Bi-Se-Te bearing tellurides, native bismuth, molybdenite, chalcopyrite and pyrrhotite were mineral phases found to be associated with gold in fractures. The Spearman correlation coefficient show strong correlation between $\mathrm{Au}$ and $\mathrm{Te}, \mathrm{Cu}, \mathrm{Co}, \mathrm{Se}, \mathrm{Bi}, \mathrm{Mo}$, and Ag $(\rho=0.730-0.619)$, moderately with As, Fe, W $(\rho=0.523-0.511)$ and slightly less with $\mathrm{U}, \mathrm{Pb}$, and $\mathrm{Ni}(\rho=0.492-0.407)$ (Ranta et al. 2018). In addition to gold, cobalt is economically important element in the Rajapalot 
area. Farajewicz (2018) studied the Co-mineral within the Rajapalot area using QEMSCAN $^{\oplus}$, SEM-based automated mineral mapping. Main host minerals for cobalt were found to be cobaltite, linnaeite and Co-pentlandite. Based on the textural observation, Farajewicz (2018) suggested that the cobaltite is related to the albitization process whereas linnaeite and Co-pentlandite formed in later sulfidation event related to the formation of pyrrhotite which remobilized and reworked the early formed cobaltite.

\section{Sampling and analytical methods}

\subsection{Sampling}

Samples were collected from the drill cores representing $\mathrm{Au}, \mathrm{Au}-\mathrm{Co}$ and $\mathrm{Co}$ mineralized intervals from Rumajärvi, Hut, Palokas and Raja prospects within the Rajapalot area based on the drill core whole-rock geochemical database of Mawson Gold Ltd. The objective was to collect different types of mineralized intervals in order to study textural locations and mineral associations of gold using SEM-AM. 19 thin sections were chosen for SEM-AM analyses. Sampled drillholes and sample intervals are given in the Electronic Appendix A.

\subsection{SEM-AM}

The FEI Quanta 650F field emission scanning electron microscope equipped with two Bruker Quantax X-Flash 5030 EDX detectors and FEI's MLA suite v. 3.1.4.686 for data acquisition were used for SEM-AM analyses of the thin sections in TU Bergakademie Freiberg, Germany. The minerals were identified based on backscattered electron (BSE) image segmentation and collection of EDXspectra. Collected EDX-spectra were classified using a list of in-house mineral spectra references. More detailed information about functionality of the MLA system can be found in Fandrich et al. (2007) and Bachmann et al. (2017). According to the aim of this study, the Grain X-ray Mapping (GXMAP) technique was carried out for all samples. Consistent operating conditions were applied at $25 \mathrm{kV}$ acceleration voltage, a probe current of $10 \mathrm{nA}$ and an acquisition time of $5 \mathrm{~ms}$. Pixel size was set to $3 \mu \mathrm{m} /$ pixel. Contrast and brightness were calibrated on $\mathrm{Au}$ (255), and the background was set to 25 . The mapping threshold was 26-255 BSE with a stepsize of 6 pixel (or $18 \mu \mathrm{m}$ ). The generated datasets were processed in the MLA Image Processing software. A coincidence threshold of $80 \%$ with standard spectra was used for the classification of the GXMAP measurements.

In addition, SPL-lt-MAP (Spare Phase Liberation Analysis-lite in combination with a mapping mode; Fandrich et al. 2007) mode was used to identify the brightest phases (BSE) and their association. Threshold for brightness was set to 190-255 for finding gold and similar rare minerals of high atomic number. As the brightness within this group of minerals is similar, the mapping mode was set to analyse chemical composition as well. Frame resolution of $1000 \mathrm{px}$ and HFW of $1000 \mu \mathrm{m}$ ( $1 \mu \mathrm{m} /$ pixel respectively) was used. The minimum area of the minerals was set to 4 pixels for reliable analyses. Acceleration voltage, emission current and acquisition time for EDX-analysis were the same as for the GXMAP mode.

\subsection{Preparation of the data for statistical analyses}

The raw geochemical database was provided by Mawson Gold Ltd. comprising whole-rock major and trace element analyses from diamond drill cores within the whole Rajapalot $\mathrm{Au}-\mathrm{Co}$ mineralized area. Geochemical data are typically reported as parts of the total composition (ppm, wt.\%). This creates problems related to the closure issue, that is, all components sum to a constant. Aitchison (1986) introduced the use of log-ratios to overcome the problem of the closed data. In this study, the data were transformed using centered log-ratio (clr) 
where each variable is divided by the geometric mean of the composition of the individual observation and then taking the logarithm. Clrtransformation was utilized using CoDaPack (Thió-Henestrosa \& Martín-Fernández 2006), freely available software for compositional data transformation. The analyses with values less than detection limit were transformed to the half of the detection limit.

\subsection{Self-organizing maps (SOM)}

The use of unsupervised neural networks has gained popularity as an alternative method for analyzing multivariate datasets by reducing the dimensionality of the multidimensional datasets by clustering the data based on similarity. One of these methods are self-organizing maps which is based on competitive learning neural networks (SOM; Kohonen 2001). Details of SOM can be found for example in Kohonen (2001). Network consists of neurons (nodes), each fully connected to the input parameters with weight vectors (Fig. 3a). Network is trained for $\mathrm{n}$ times and during training cycle, initially randomly initialized weights of the neurons are updated by selecting winning neuron based on having smallest distance (e.g. Euclidean distance) from randomly selected input. By repeating this process over $\mathrm{n}$ training cycles, neurons eventually settle into stable positions within the SOM space

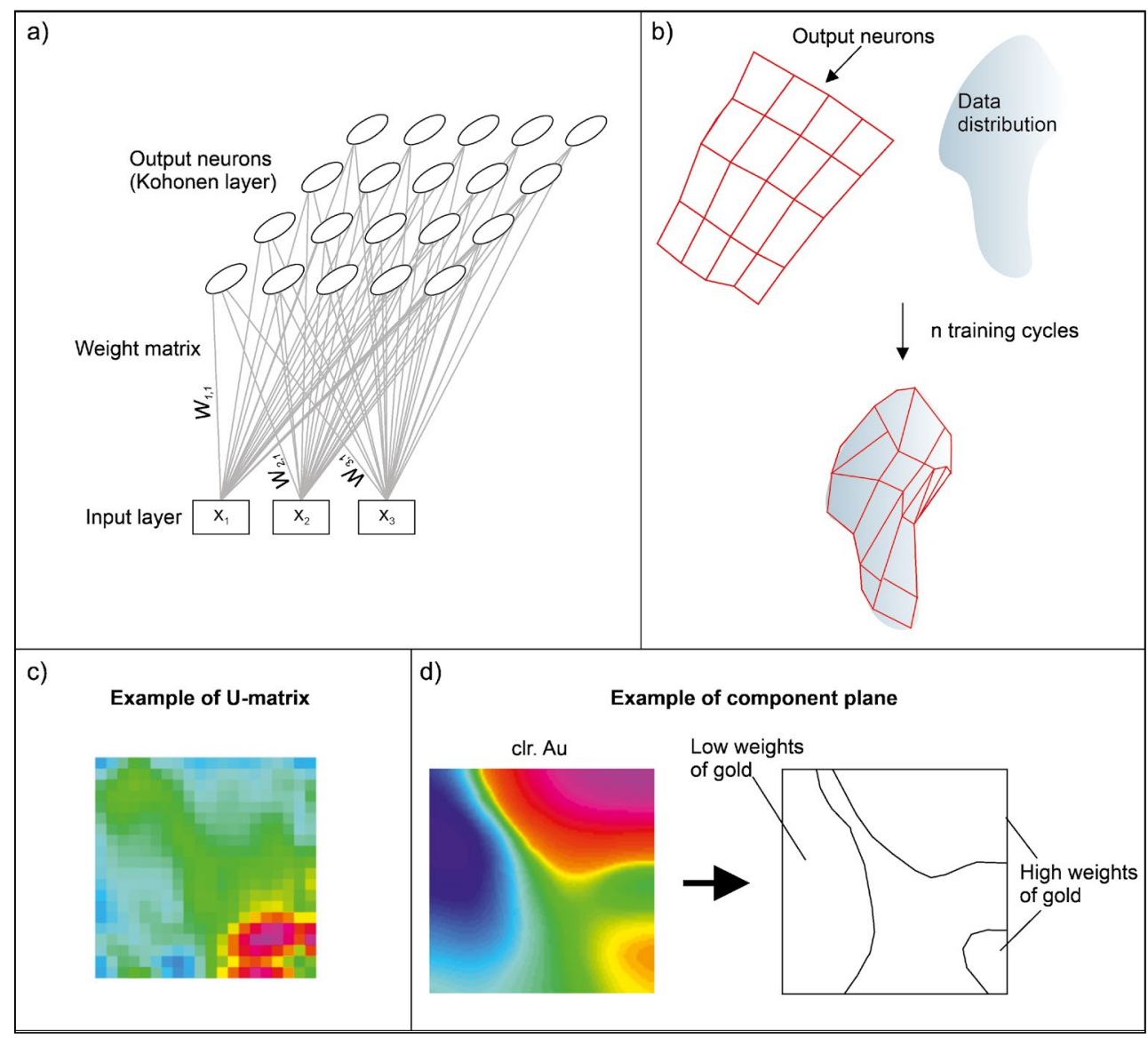

Figure 3. SOM illustrations. a) Basic structure of SOM with input layer fully connected with the neurons. b) Illustration of arrangement of neurons during the training process of SOM. c) Example of U-matrix with cold colors (blue areas) indicating regions where neurons are close to each other (clusters) and warmer colors indicating more separations of individual neurons. d) Example of single component plane showing region of high and low weights of the respective element. 
approximating the original data distribution (Fig. 3b). In this study, 1000 training cycles were used. The location of neurons are reflecting clusters of input data which have similarities. SOM can deal with non-Gaussian data which is one of the main advantages of this method over traditional multivariate statistics which generally assume normally distributed datasets. SOM highlights nonlinear associations by topological transformations of the original dataset. In line with other disciplines (e.g. finance, astronomy; Kaski et al. 1998; CarciaBerro et al. 2003), SOM usage has increased in geosciences over the last decade (e.g. Klose 2006). Log-transformations are not compulsory in the use of SOM, but it is recommended that the variables should have similar variance (Kohonen 2001). After training of SOM, distances between the neurons can be visualized by U-matrix (unified distance matrix) where coloring of the matrix indicates the distance of neuron compared to the adjacent neuron (Fig. 3c). Areas where neurons are close to each other (blue areas in Fig. 3c), indicates clusters in the datasets and areas with neurons in more distance from each other, as cluster separators. U-matrix can be used to determine the number of possible clusters in the datasets (using e.g. K-means clustering). In exploratory analysis of the data, we can use the component planes of each individual input parameter (Fig. 3d). In component plane, single variables are visualized for all the map units in the SOM. Each node has the same position regardless of the variable visualized and therefore different variables can be compared. Similarities between different variables can be visually identified by comparing similar patterns between different component planes by visually overlaying them on top of each other.

\section{Results}

\subsection{SEM-AM mapping}

Size distribution of the gold grains using electronic sieving provided by the FEI's MLA software are shown in the Fig. 4 and Table 1. Altogether, 623 gold grains were detected from the studied samples. In terms of gold grain size in the studied samples, Palokas and Raja shows more fine-grained particles between 1-30 $\mu \mathrm{m}$ compared to the Hut and Rumajärvi with more coarser grains with overall grain size of gold between 1-60 $\mu \mathrm{m}$ and 1-90 $\mu \mathrm{m}$, respectively (Fig. 4).

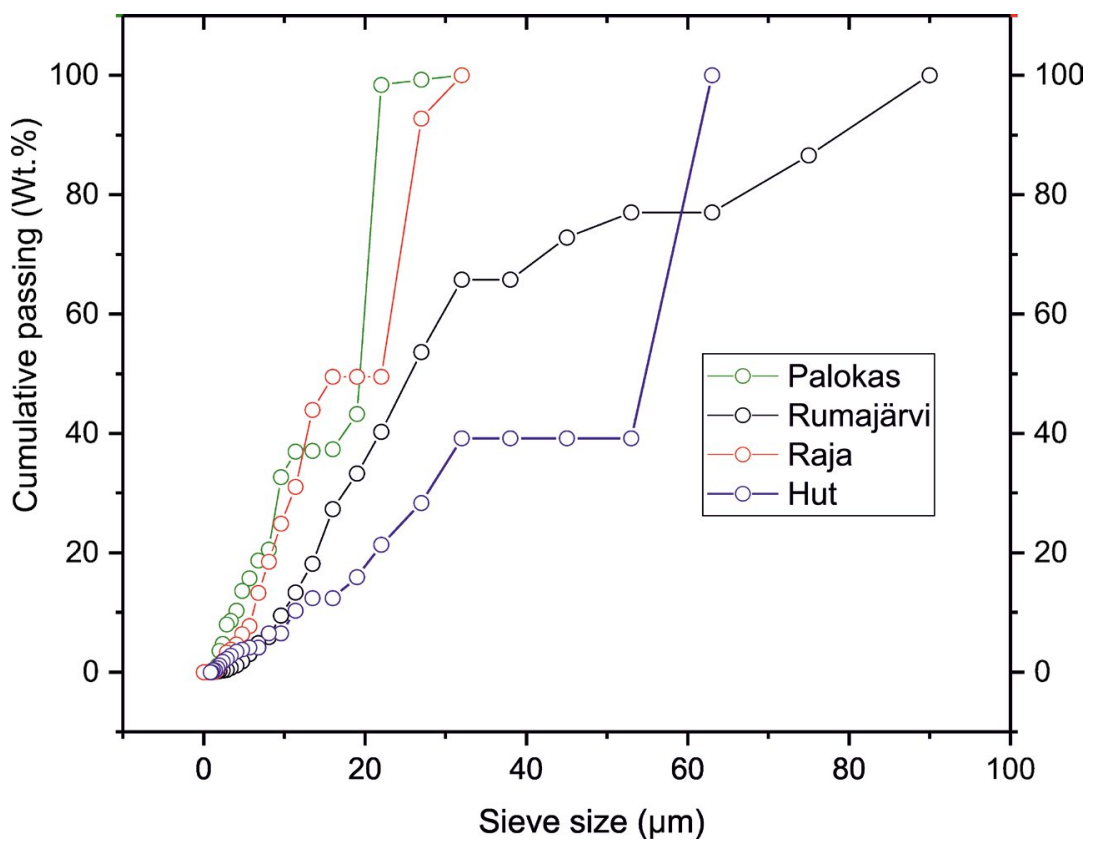

Figure 4. Cumulative grain size distribution of gold based on the electronic sieving from the Rajapalot area divided into separate occurrences. 
Table 1. Sieve sizes used for electronic sieving and cumulative grain size distribution (Wt.\%) of gold grains in different occurrences within the Rajapalot area.

\begin{tabular}{|c|c|c|c|c|}
\hline Sieve Size $(\mu \mathrm{m})$ & Palokas $(n=161)$ & Raja (n=93) & Rumajärvi (n=299) & Hut $(n=70)$ \\
\hline 90 & & & 100,0 & \\
\hline 75 & & & 86,6 & \\
\hline 63 & & & 77,0 & 100,0 \\
\hline 53 & & & 77,0 & 39,2 \\
\hline 45 & & & 72,8 & 39,2 \\
\hline 38 & & & 65,8 & 39,2 \\
\hline 32 & 100,0 & 100,0 & 65,8 & 39,2 \\
\hline 27 & 99,3 & 92,8 & 53,6 & 28,3 \\
\hline 22 & 98,4 & 49,5 & 40,3 & 21,3 \\
\hline 19 & 43,3 & 49,5 & 33,2 & 15,9 \\
\hline 16 & 37,3 & 49,5 & 27,3 & 12,4 \\
\hline 13,5 & 37,0 & 43,9 & 18,1 & 12,4 \\
\hline 11,4 & 36,9 & 31,0 & 13,4 & 10,3 \\
\hline 9,6 & 32,7 & 24,9 & 9,5 & 6,5 \\
\hline 8,1 & 20,5 & 18,5 & 5,9 & 6,5 \\
\hline 6,8 & 18,7 & 13,2 & 4,9 & 4,1 \\
\hline 5,7 & 15,7 & 7,7 & 3,0 & 4,1 \\
\hline 4,8 & 13,6 & 6,3 & 1,8 & 3,7 \\
\hline 4,1 & 10,3 & 4,7 & 1,1 & 3,4 \\
\hline 3,4 & 8,6 & 3,8 & 0,7 & 2,8 \\
\hline 2,9 & 8,0 & 3,3 & 0,3 & 2,2 \\
\hline 2,4 & 4,7 & 1,9 & 0,3 & 1,7 \\
\hline 2 & 3,6 & 0,9 & 0,2 & 1,1 \\
\hline 1,75 & 1,1 & 0,7 & 0,1 & 0,7 \\
\hline 1,45 & 0,2 & & 0,1 & 0,3 \\
\hline 1,2 & 0,2 & & 0,1 & 0,3 \\
\hline
\end{tabular}

\subsubsection{Rumajärvi}

The studied sample is albite-rich interval showing > $6 \mathrm{~g} / \mathrm{t}$ Au in a one meter sample length (Fig. 5a). The processed thin section maps are shown in Fig. $5 \mathrm{~b}$. Samples are representing albitized metasedimentary rocks with varying amount of biotite. Tourmaline, chlorite and orthoamphiboles are common minerals in these samples. The main sulfide is pyrrhotite along with minor pyrite and chalcopyrite which are disseminated throughout the samples. Magnetite, ilmenite, rutile and scheelite are the oxides present. The different textural settings of gold are shown in the Fig. $5 \mathrm{c}$ and representative photomicrographs are shown in the Fig. 6a-e. Gold and linnaeite are associated with sulfides in the given sample (Fig. 6a and b), as disseminated native crystals within the albite matrix (Fig. 6c and d) and in association with uraninite within the albitized rock matrix (Fig. 6e). The most common association of gold is with the silicates. The main Co-mineral in the studied samples is linnaeite which is closely associated with pyrrhotite (Fig. $5 \mathrm{~d}$ and $6 \mathrm{f}$ ) and distributed throughout the sulfidized samples. In addition, minor cobaltite associated with the disseminated pyrrhotite was found (Fig. 5d).

\subsubsection{Hut}

Garnet-bearing cordierite-orthoamphibole rocks with fine grained albite-quartz matrix showing $>10 \mathrm{~g} / \mathrm{t} \mathrm{Au}$ in a one meter sample length were chosen from the Hut (Fig. 7a and b). The processed thin section maps from two samples are shown in Fig. 7b. Biotite is common with small amount of chlorite. Pyrrhotite is the predominant sulfide along with lesser amounts of pyrite and chalcopyrite. Main oxide minerals are magnetite and ilmenite. 


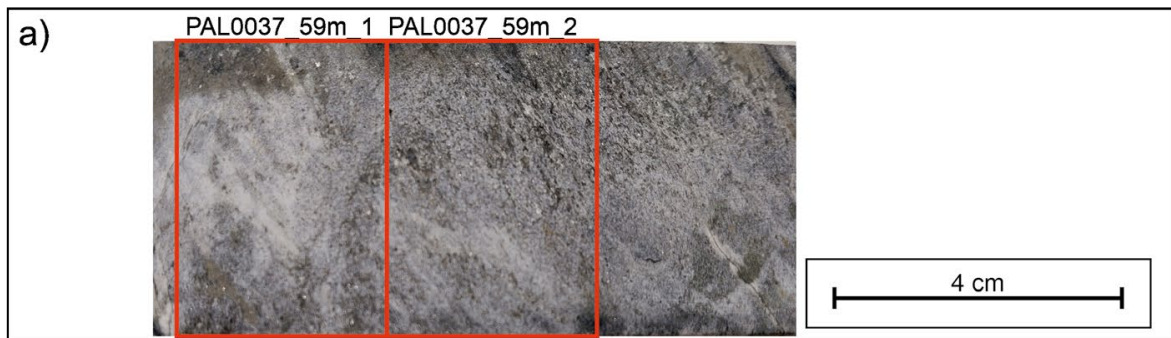

b) PAL0037_59m_1

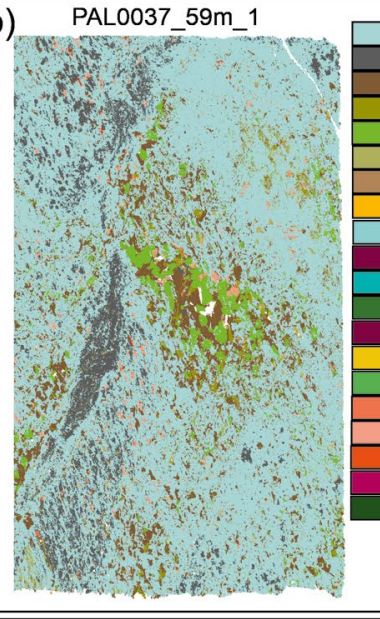

c)

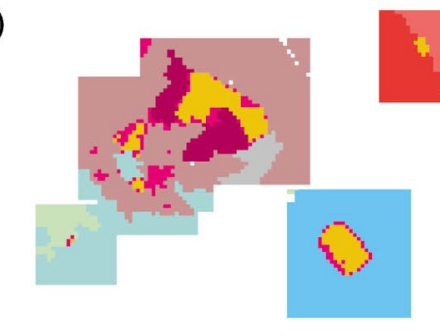

Albite Quartz Biotite Tourmaline Amphibole Sericite Garnet Apatite Zircon Monazite IImenite Cobaltite Gold Rutile Pyrite Pyrrhotite Chalcopyrite Linnaeite Fe-oxide
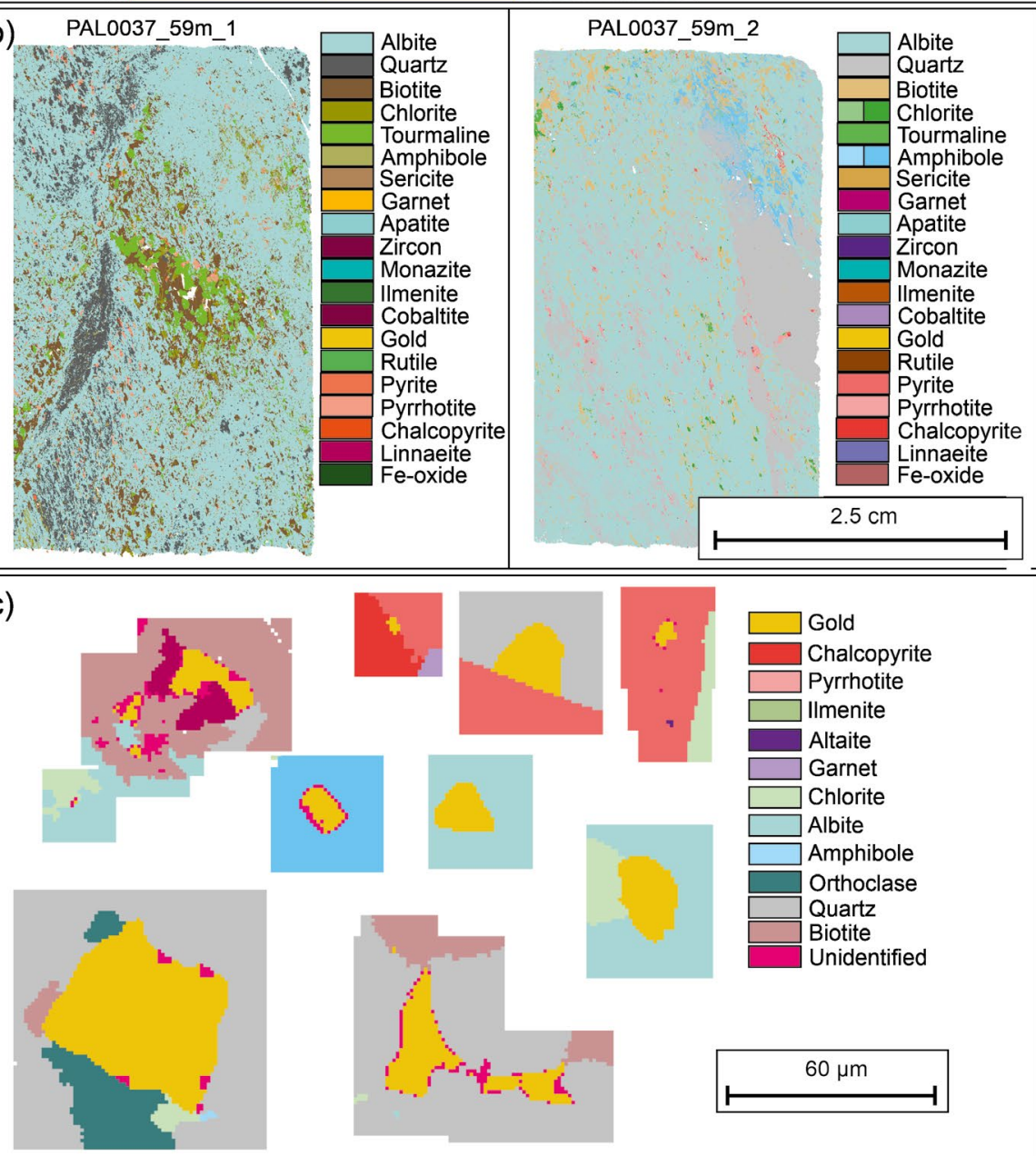

d)
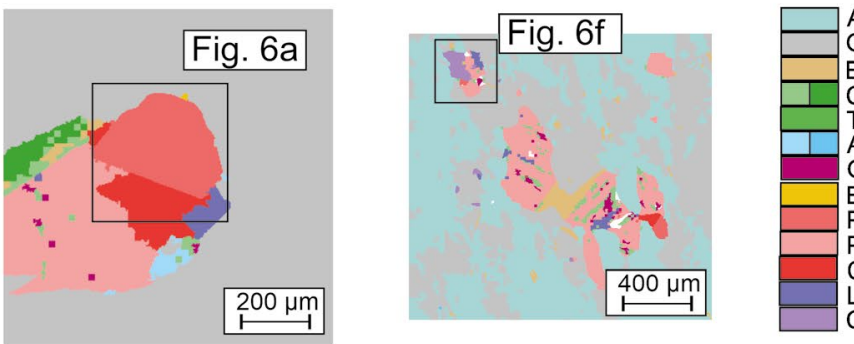

Albite

Quartz

Biotite

Chlorite

Tourmaline

Amphibole

Garnet

Electrum

Pyrite

Pyrrhotite

Chalcopyrite

Linnaeite

Cobaltite
Figure 5. Rumajärvi mineralized sample. a) Photograph of the drill core. b) Mineral maps of the thin sections.

c) Textural setting of gold based on the automated mineral mapping. d) Textural setting of the main Co-minerals based on the automated mineral mapping. 
Figure 6. Photomicrographs and MLA mineral map of textural setting of gold and main Co-minerals in Rumajärvi. a) and b) gold associated with sulfides. c) and d) disseminated gold grains within albite matrix. e) gold associated with uraninite within albite matrix.f) Cobaltite and linnaeite closely associated with pyrrhotite. Abbreviations: $\mathrm{Au}=$ gold, $\mathrm{Py}=$ pyrite, $\mathrm{Cpy}=$ chalcopyrite, $\mathrm{Po}=$ Pyrrhotite, $\mathrm{Ur}=$ uraninite, $\mathrm{Cbl}$ $=$ cobaltite, Lin $=$ Linnaeite, $\mathrm{Qz}=$ Quartz.
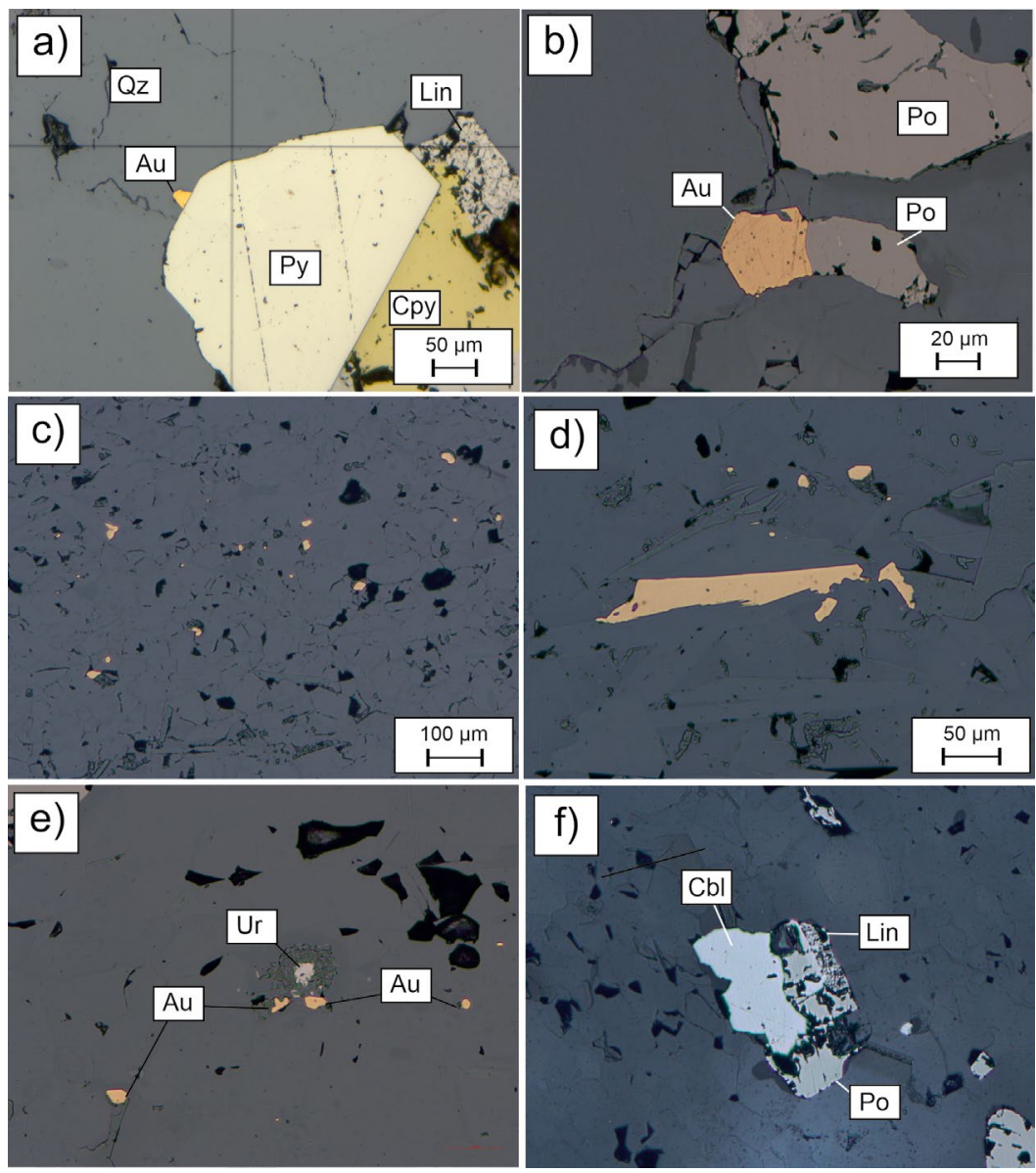

Rocks are highly deformed and folding is clearly evident at the thin section scale (Fig. 7b). Gold is found to be associated with sulfides (Fig. $7 c$ and Fig. 8a-b), within quartz inclusions in magnetite (Fig. 8c) and fractures of Garnet (Fig. 8d). No cobaltite and linnaeite were identified from the collected samples.

\subsubsection{Palokas}

Samples from the Palokas represents sulfidebrecciated albite rocks (Fig. 9a-b) and sulfidized cordierite-orthoamphibole rocks \pm Garnet (Fig. 10a-b; Garnet-bearing rock not shown). The main sulfides are pyrrhotite and pyrite. In albite rocks, gold is found within the pyrrhotite or within albite and quartz (Fig. 9c). Cobaltite is found as disseminated grains within the albite clasts (Fig. 9d).
Linnaeite is associated with the brecciating pyrrhotite (Fig. 9d). In cordierite-orthoamphibole rocks, gold is found within several silicate phases, including albite, chlorite, muscovite, biotite and Garnet (Fig. 10c and Fig. 11a-c). Gold is also found to be associated with pyrrhotite and cobaltite (Fig. 10c), as well with magnetite and ilmenite (Fig. 10c).

\subsubsection{Raja}

Samples from Raja represents sulfidized and sericitized quartz-albite rocks (Fig. 12a-b) and sulfidized and chloritized quartz-albite rocks (Fig. 13a-b). Pyrrhotite dominates over chalcopyrite. In intensively sericitized rocks, gold is found within silicate phases including albite, quartz, chlorite and sericite (Fig. 12c) associated 

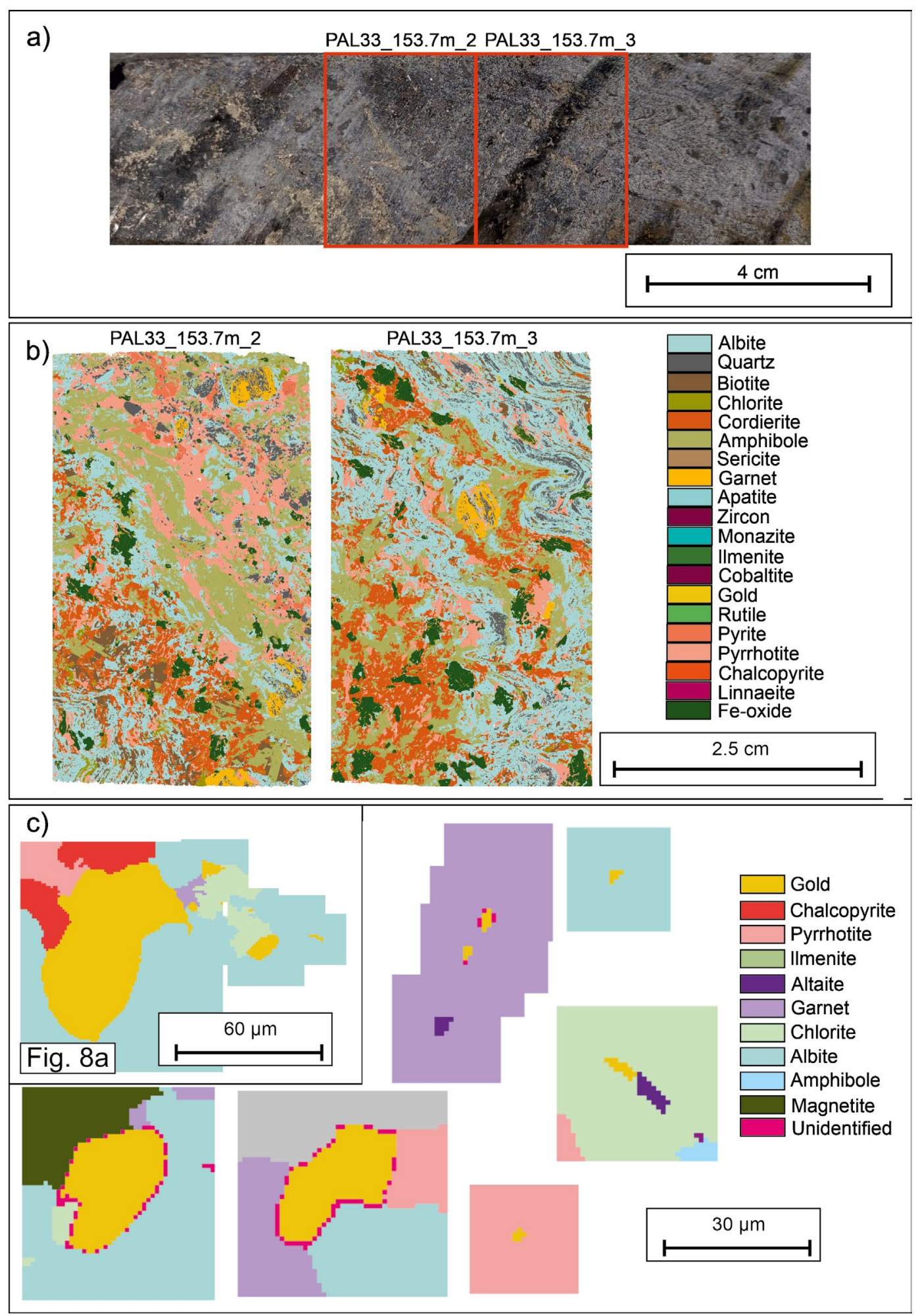

Figure 7. Hut mineralized sample. a) Photograph of the drill core. b) Mineral maps of the thin sections. c) Textural setting of gold based on the automated mineral mapping. d) Syn-kinematic garnet porphyroblast showing undulating pattern corresponding to the main folded fabric. 
Figure 8. Photomicrographs of textural setting of gold in Hut. a) and b) gold associated with sulfides. c) gold within quartz inclusion in magnetite. and d) gold in fractures of garnet. Abbreviations: $\mathrm{Au}=$ gold, $\mathrm{Cpy}=$ chalcopyrite, $\mathrm{Po}=$ Pyrrhotite, $\mathrm{TeBi}=$ Te-Bi-mineral phase, Qz = Quartz.
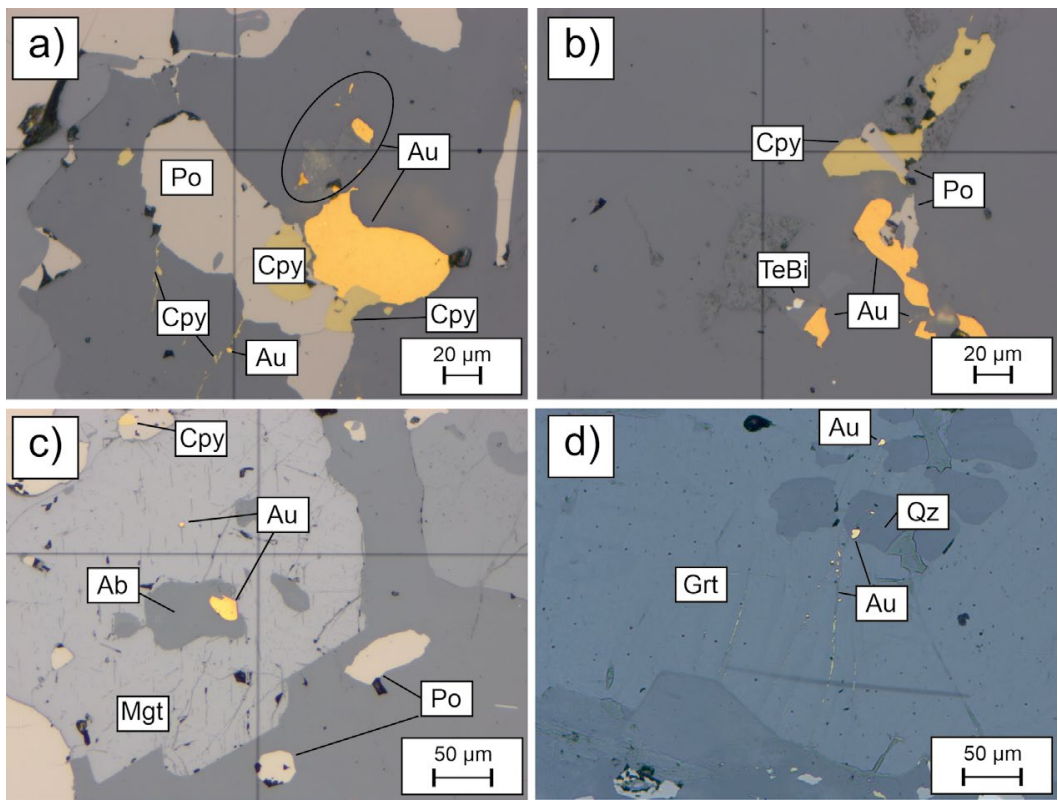

with Bi-Tellurides and altaite (Fig. 12c and 14b). In addition, gold is found and associated with pyrrhotite, chalcopyrite and molybdenite (Fig. 12c and 14a). In chloritized quartz-albite-biotite rocks, gold is found within chlorite, chalcopyrite, pyrrhotite (Fig.13c). Cobaltite is found within the sericite and albite in the sericitized samples (Fig. 12d) and linnaeite is closely associated with pyrrhotite (Fig. 12d). In the chloritized rocks, cobaltite is found within quartz and closely associated with wolframite (Fig. 13d).

\subsection{Self-organizing maps}

The clustering and distribution of the data on SOM component planes is an intuitive way of identifying associations from multi-component data. The SOM were run for Rumajärvi, Raja, Hut and Palokas individually in order to investigate possible differences. In particular, the focus was to look at the relationship of $\mathrm{Au}$ and Co. The grid size of the SOM for each different area were chosen based on the number of observations, following guidelines of Vesanto et al. (2000). Fig. 15-17 component planes for chosen elements. Unified distance- and count matrices are provided in the Electronic Appendix B. Elemental weights for SOM component planes (Fig. 15 and 17) are given in the Electronic Appendix C.

In Rumajärvi, $18 \times 18$ grid size was used for the SOM (Fig. 15a). Inspection of $\mathrm{Au}$ and $\mathrm{Co}$ component planes (Fig. 15a) reveals domains with 1) high weights of Au and Co as well as W, U, Te, As, $\mathrm{Mo}, \mathrm{Bi}, \mathrm{Cu}, \mathrm{Ni}, \mathrm{Se}, \mathrm{Ag}, \mathrm{Mg}, \mathrm{Fe}, \mathrm{Zn}$ and Ca showing high weights within the domain (Fig. 16a). 2) High weights of Au and low weights of Co as well as W, $\mathrm{U}, \mathrm{Te}, \mathrm{As}, \mathrm{Mo}, \mathrm{Bi}, \mathrm{Ni}, \mathrm{Se}, \mathrm{Na}, \mathrm{Ag}$ and $\mathrm{Mg}$ showing high weights within the domain (Fig. 16a). 3) High weights of $\mathrm{Co}$ and low weights of $\mathrm{Au}$ as well as $\mathrm{Bi}$, $\mathrm{Cu}, \mathrm{Ni}, \mathrm{Ag}, \mathrm{Fe}, \mathrm{Zn}, \mathrm{K}$, Ca showing high weights within the domain (Fig. 16a). Filtering the data above $0.1 \mathrm{~g} / \mathrm{t}$ Au and using $12 \times 12$ grid size for SOM (Fig. 17a), Au has partially overlapping areas with W, Mo, Na, Mg, Fe, K and Ca. Co partially overlaps with $\mathrm{U}, \mathrm{Te}, \mathrm{As}, \mathrm{Mo}, \mathrm{Bi}, \mathrm{Cu}, \mathrm{Ni}, \mathrm{Se}, \mathrm{Na}, \mathrm{Ag}$ and $\mathrm{Fe}$.

For Raja, grid size of 20x20 was used (Fig. 15b). Inspection of $\mathrm{Au}$ and $\mathrm{Co}$ component planes (Fig. 15b) reveals domains with 1) high weights of $\mathrm{Au}$ and $\mathrm{Co}$ as well as Te, Ad, W, U, Bi, Cu, Ni, Se, $\mathrm{Ag}, \mathrm{Fe}, \mathrm{Na}$ and $\mathrm{Zn}$ showing high weights within the domain (Fig. 16b). 2) high weights of $\mathrm{Au}$ and low weights of $\mathrm{Co}$ as well as $\mathrm{U}, \mathrm{Te}, \mathrm{As}, \mathrm{Mo}, \mathrm{Ni}, \mathrm{Se}, \mathrm{Na}$, $\mathrm{Mg}$, Ca showing high weights within the domain (Fig. 16b).3) high weights of Au and low weights of 


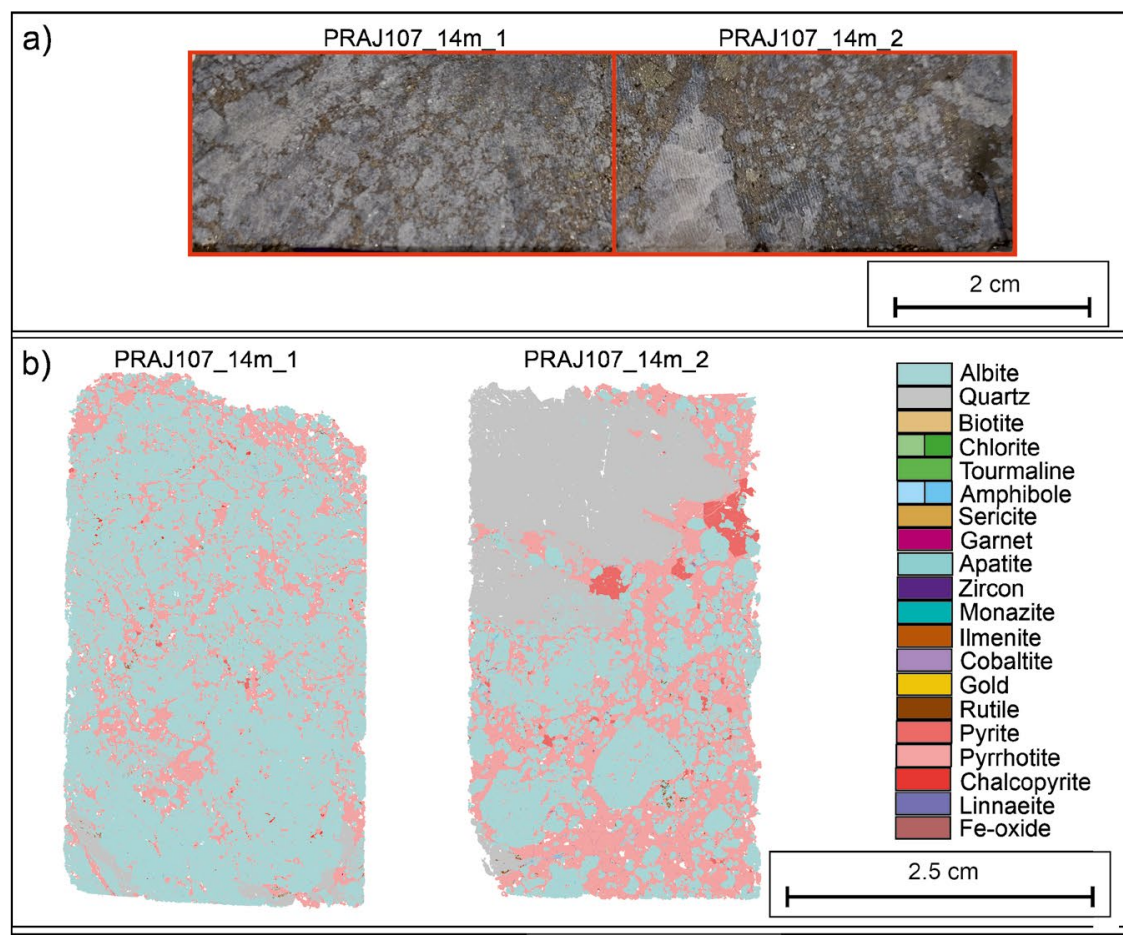

c)
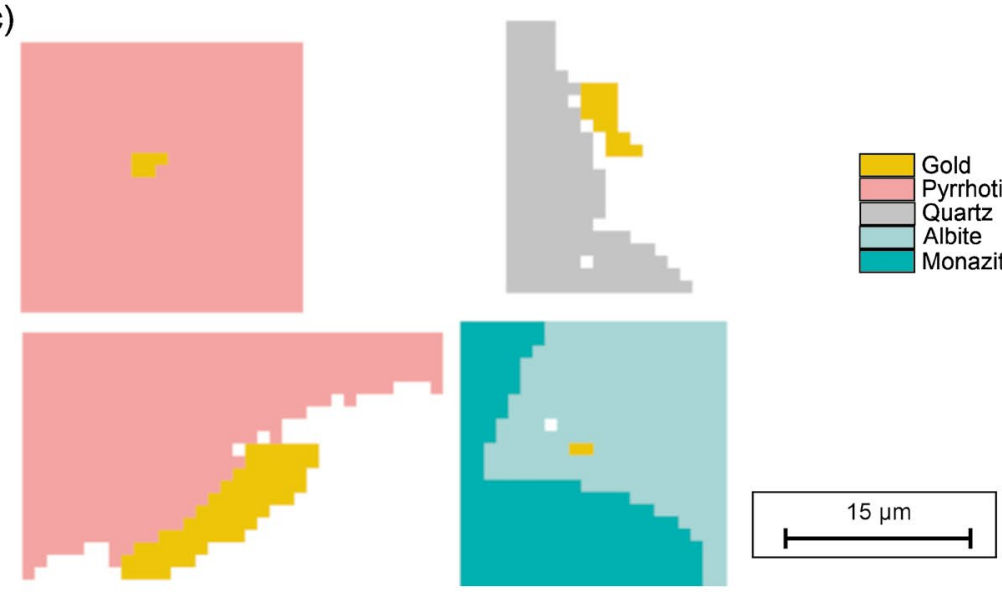

d)

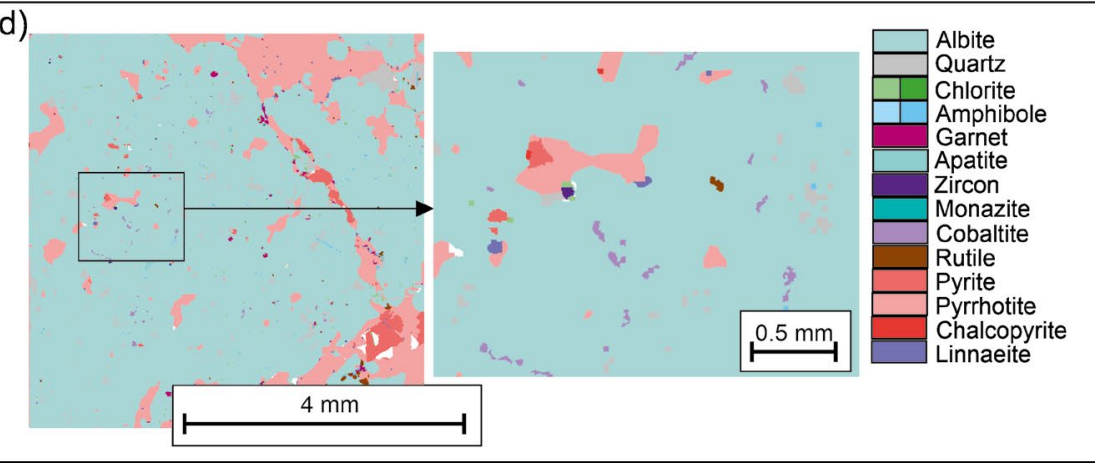

Figure 9. Palokas

mineralized sample. a)

Photograph of the drill core.

b) Mineral maps of the thin sections. c) Textural setting of gold based on the automated mineral mapping. d) Fine dissemination of linnaeite within pyrrhotite (left) and fine dissemination of cobaltite within albite clast (right) 

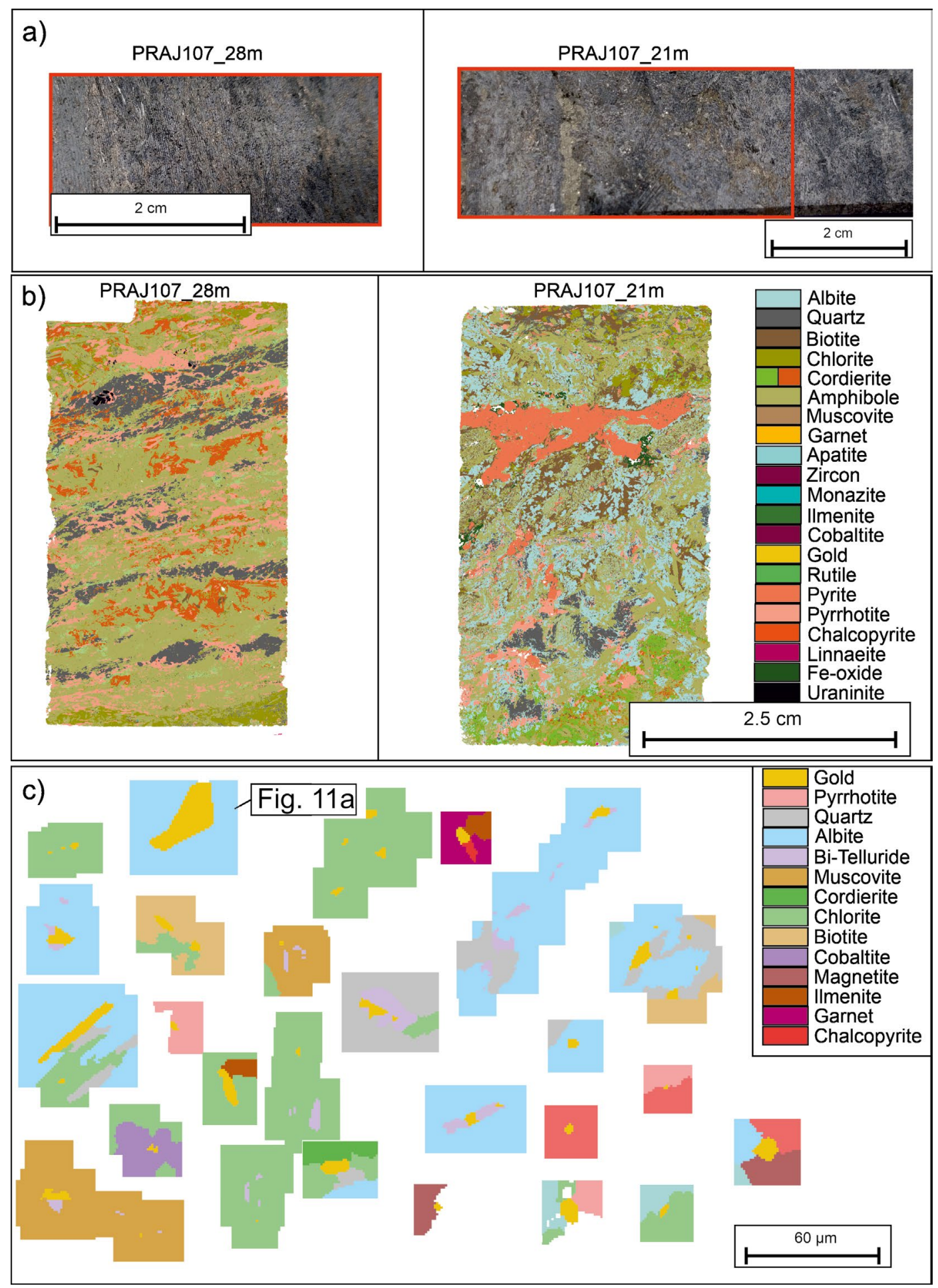

Figure 10. Palokas mineralized samples. a) Photographs of the drill core. b) Mineral maps of the thin sections. c) Textural setting of gold based on the automated mineral mapping. 

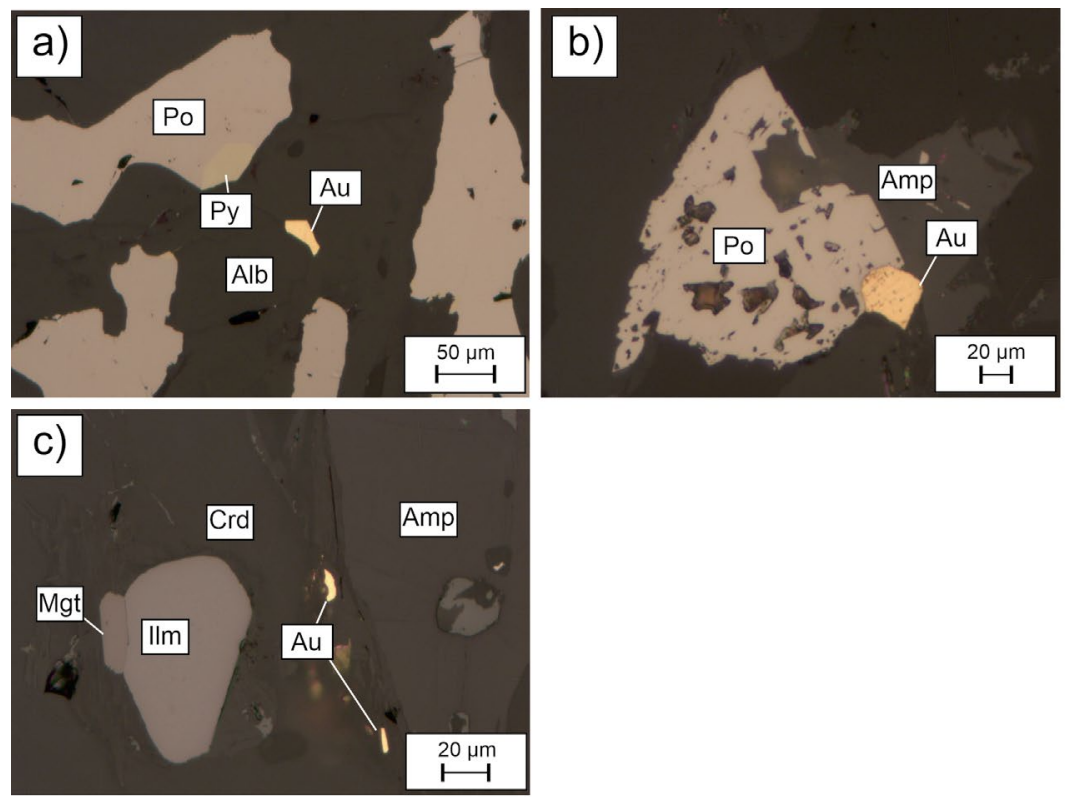

Co as well as W, U, Te, As, Mo, Bi, Cu, Ag, Zn and Kshowing high weights within the domain. 4) High weights of $\mathrm{Co}$ and low weights of $\mathrm{Au}$ as well as $\mathrm{Cu}$, $\mathrm{Ni}, \mathrm{Ag}, \mathrm{Mg}, \mathrm{Fe}, \mathrm{Zn}$ and $\mathrm{Ca}$ showing high weights within the domain (Fig. 16b). Filtering the data above $0.1 \mathrm{~g} / \mathrm{t}$ Au and using 12x12 grid size for SOM (Fig. 17b), Au is partially overlapping areas with Co, W, U, Te, As, Mo, Bi, Cu, Ni, Se, Ag, Fe and K. Co partially overlaps with $\mathrm{Au}, \mathrm{W}, \mathrm{U}, \mathrm{Te}, \mathrm{As}, \mathrm{Mo}, \mathrm{Bi}, \mathrm{Cu}$, $\mathrm{Ni}, \mathrm{Se}, \mathrm{Ag}, \mathrm{Fe}, \mathrm{Zn}$, and K. Au-Co relationship in the component planes shows fields of Au-only, Co-only and $\mathrm{Au}-\mathrm{Co}$.

9x9 grid size was used for the SOM in the Hut area (Fig. 15c). Inspection of $\mathrm{Au}$ and $\mathrm{Co}$ component planes (Fig. 15c) reveals domains with 1) high weights of $\mathrm{Au}$ and $\mathrm{Co}$ as well as $\mathrm{W}, \mathrm{U}, \mathrm{Te}$, As, $\mathrm{Mo}, \mathrm{Bi}, \mathrm{Cu}, \mathrm{Ni}, \mathrm{Se}, \mathrm{Ag}, \mathrm{Fe}, \mathrm{Zn}$ and $\mathrm{K}$ showing high weights within the domain (Fig. 16c). 2) high weights of $\mathrm{Au}$ and low weights of $\mathrm{Co}$ as well as $\mathrm{W}, \mathrm{U}$, $\mathrm{Te}, \mathrm{As}, \mathrm{Mo}, \mathrm{Bi}, \mathrm{Se}, \mathrm{Ag}$ and $\mathrm{Ca}$ showing high weights within the domain (Fig. 16c). 3) High weights of $\mathrm{Co}$ and low weights of $\mathrm{Au}$ as well as $\mathrm{Cu}, \mathrm{Ni}, \mathrm{Ag}$, $\mathrm{Fe}, \mathrm{Zn}, \mathrm{Ca}$ and $\mathrm{K}$ showing high weights within the domain (Fig. 16c). Filtering the data above $0.1 \mathrm{~g} / \mathrm{t}$ $\mathrm{Au}$ and using $6 \times 6$ grid size for SOM (Fig. 17c), Au is showing bimodal distribution in the component
Figure 11.

Photomicrographs of textural setting of gold in Palokas. a) and b) gold associated with sulfides. c) gold in the boundary of cordierite and amphibole. Abbreviations: $\mathrm{Au}=$ gold, $\mathrm{Py}=$ Pyrite, $\mathrm{Po}=$ Pyrrhotite, Alb = Albite, Amp = Amphibole, $\mathrm{IIm}=$ Ilmenite, $\mathrm{Crd}=$ Cordierite plane and Au-Co, Au-only and Co-only areas can be inferred. Au-Co are overlapping with W, Te, As, Mo, $\mathrm{Zn}$ and to some extent with $\mathrm{U}$ and $\mathrm{Ni}$. Au-only area (lower right corner) overlaps with $\mathrm{Na}, \mathrm{Ag}, \mathrm{Se}, \mathrm{Te}$ and K. Co-only overlaps with Te, $\mathrm{Mo}, \mathrm{Bi}, \mathrm{Cu}, \mathrm{Ni}, \mathrm{Se}, \mathrm{Ag}$, $\mathrm{Mg}, \mathrm{Fe}, \mathrm{Ca}$ and $\mathrm{K}$.

For Palokas, grid size of $22 \times 22$ was used (Fig. 15d). Inspection of $\mathrm{Au}$ and Co component planes (Fig. 15d) reveals domains with 1) high weights of $\mathrm{Au}$ and $\mathrm{Co}$ as well as W, U, Te, As, Mo, $\mathrm{Bi}, \mathrm{Cu}, \mathrm{Ni}, \mathrm{Se}, \mathrm{Ag}, \mathrm{Fe}$ and $\mathrm{Zn}$ showing high weights within the domain (Fig. 16d). 2) high weights of $\mathrm{Au}$ and low weights of $\mathrm{Co}$ as well as $\mathrm{Te}, \mathrm{Bi}, \mathrm{Cu}$, $\mathrm{Fe}, \mathrm{Zn}, \mathrm{K}$ and $\mathrm{Ca}$ showing high weights within the domain (Fig. 16d). 3) High weights of Co and low weights of Au as well as $\mathrm{U}, \mathrm{Te}, \mathrm{As}, \mathrm{Mo}, \mathrm{Se}, \mathrm{Na}$ and $\mathrm{Ag}$ showing high weights within the domain (Fig. 16d). Filtering the data above $0.1 \mathrm{~g} / \mathrm{t} \mathrm{Au}$ and using $12 \times 12$ grid size for SOM (Fig. 17d), Au is showing weighting distribution in the component plane where $\mathrm{Au}-\mathrm{Co}, \mathrm{Au}$-only and Co-only areas can be inferred. Au-Co are overlapping with W, U, Te, $\mathrm{As}, \mathrm{Mo}, \mathrm{Bi}, \mathrm{Cu}, \mathrm{Ni}, \mathrm{Se}, \mathrm{Ag}, \mathrm{Fe}$ and $\mathrm{Zn}$. Au-only area (lower left corner) overlaps clearly with W, Te, Bi, Ag, $\mathrm{Fe}$ and $\mathrm{Zn}$. Co-only overlaps with $\mathrm{As}, \mathrm{Cu}, \mathrm{Ni}, \mathrm{Se}, \mathrm{Fe}$ and Ag. 

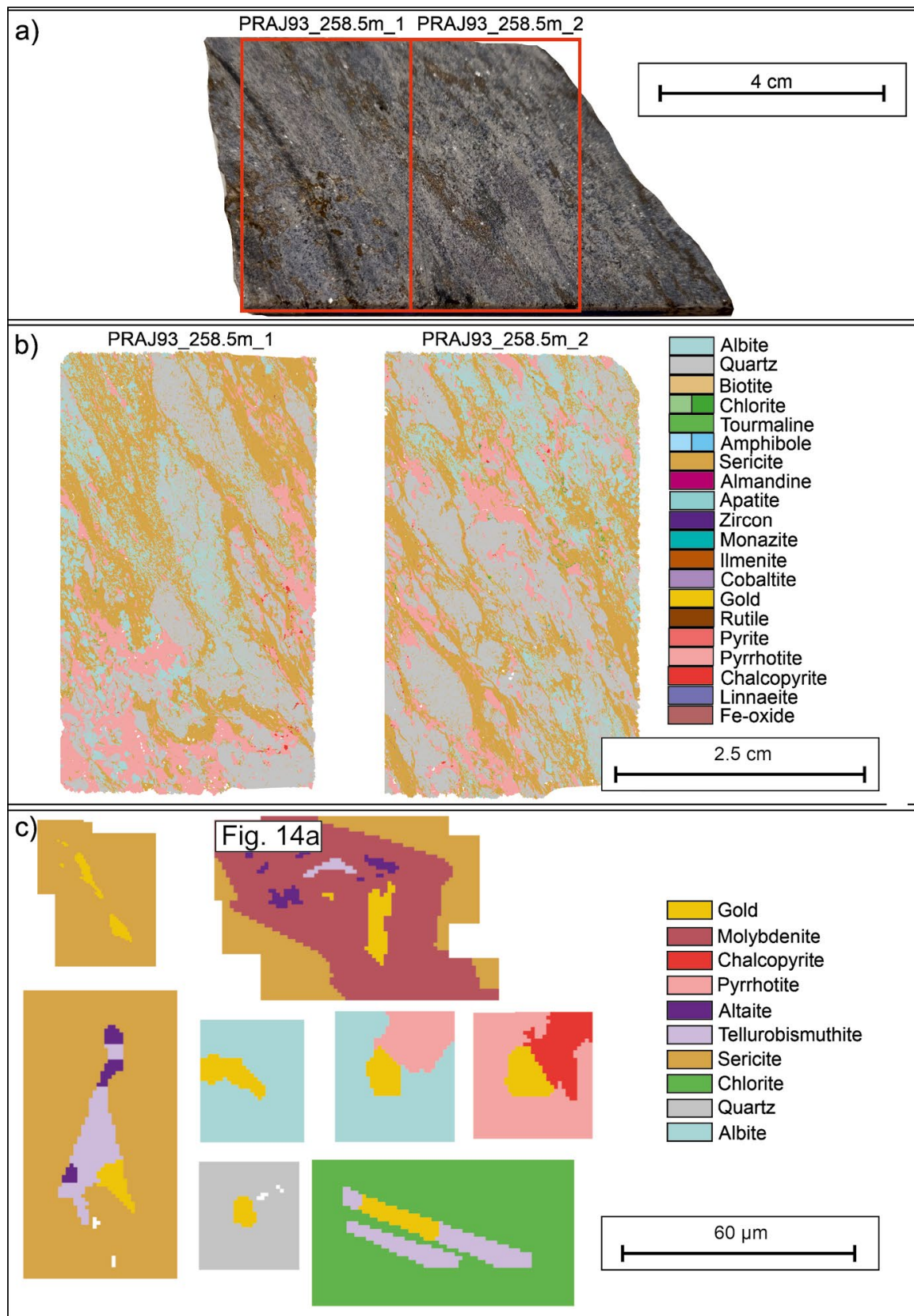

Figure 12. Raja mineralized sample. a) Photograph of the drill core. b) Mineral maps of the thin sections. c) Textural setting of gold based on the automated mineral mapping. d) Textural setting of main Co-minerals based on the automated mineral mapping.

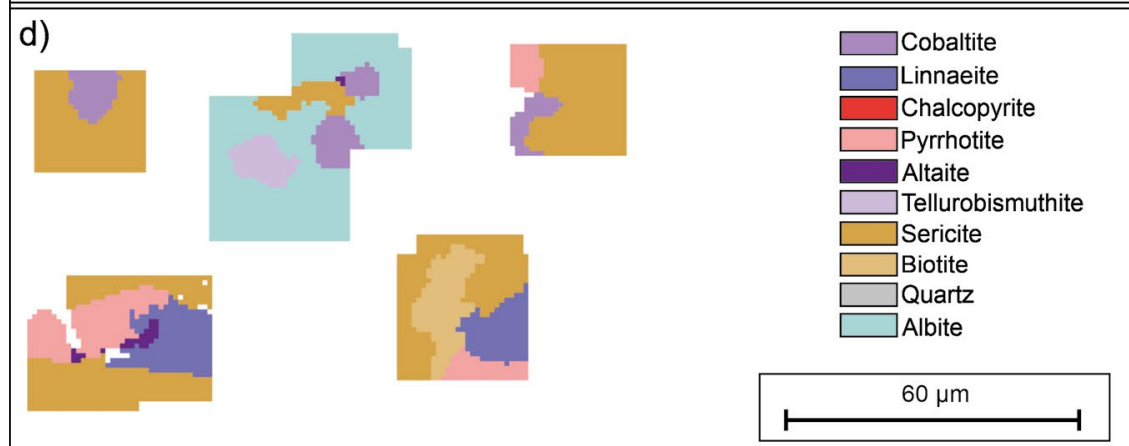



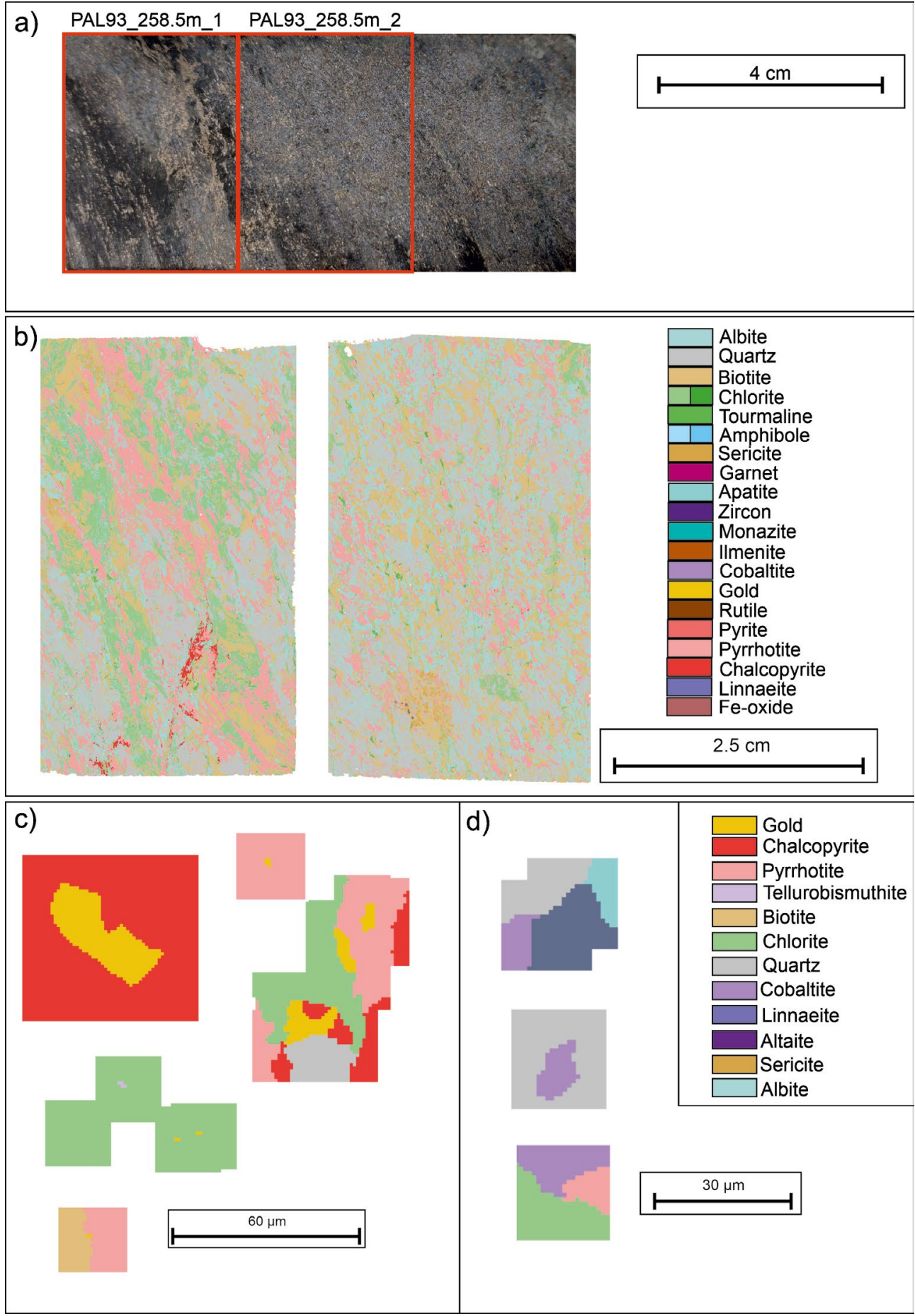

Figure 13. Raja mineralized sample. a) Photograph of the drill core. b) Mineral maps of the thin sections. c) Textural setting of gold based on the automated mineral mapping. d) Textural setting of main Co-minerals based on the automated mineral mapping. 
Figure 14. Photomicrographs of textural setting of gold in Raja. a) Gold closely associated with molybdenite and Te-Bi mineral. b) Gold inclusion in Te-Bi mineral. Abbreviations: $\mathrm{Au}=$ gold, $\mathrm{TeBi}=$ Te-Bi mineral, $\mathrm{Mdt}=$ Molybdenite.
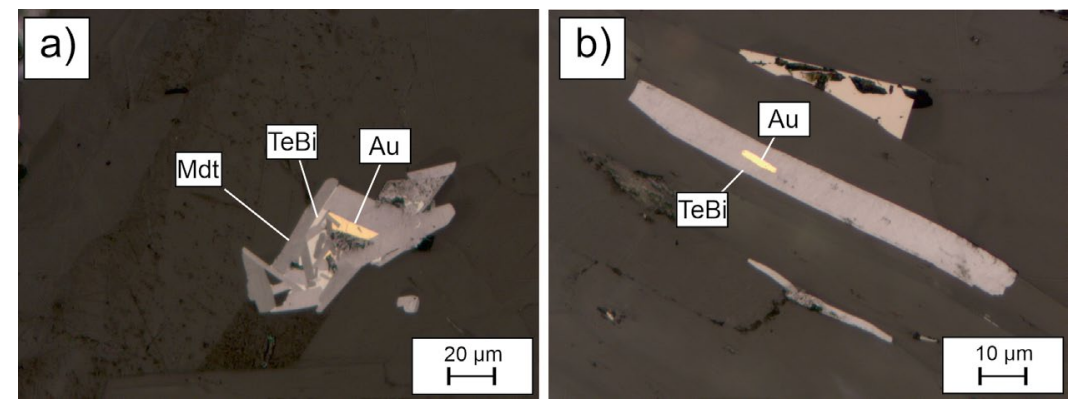

a)

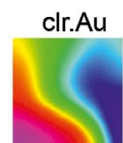

clr.Te
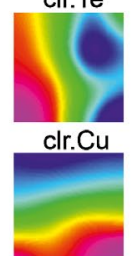

clr.Ag
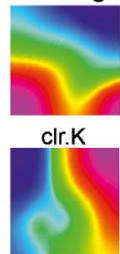

c)

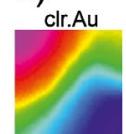

clr.Te

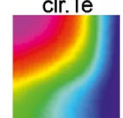

clr.Cu

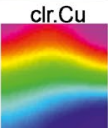

clr.Ag

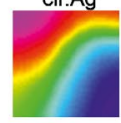

clr.Ca

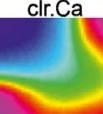

Rumajärvi

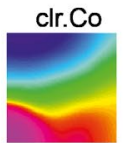

clr.As

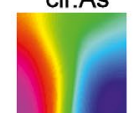

clr.Ni
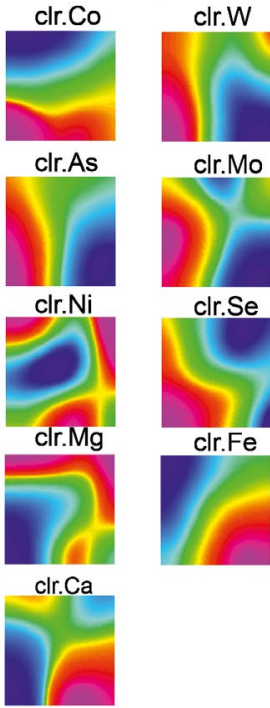

clr.Mo

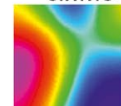

clr.Se

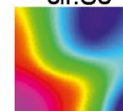

clr.Fe
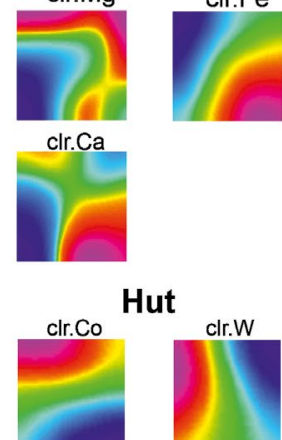

clr.As

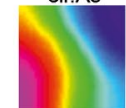

clr.Ni
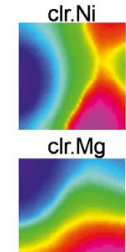

clr.K

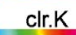

Hut

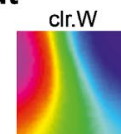

clr.Mo
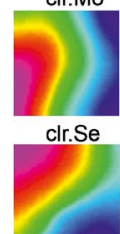

$\mathrm{clr} F \mathrm{Fe}$

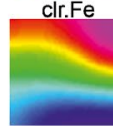

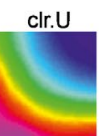

clr.Bi

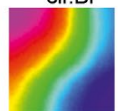

clr. Na
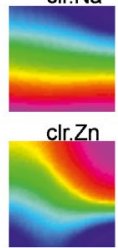

b)
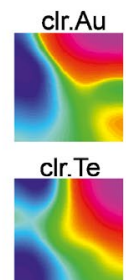

clr.Cu

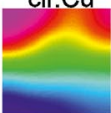

clr.Ag
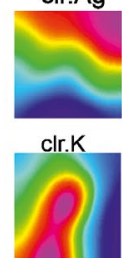

d)
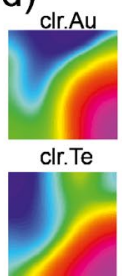

clr.Cu
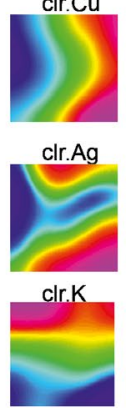

Raja

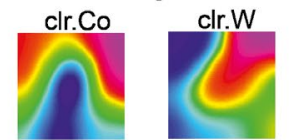

clr.As

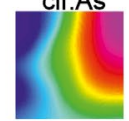

clr.Mo

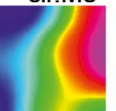

clr.Se

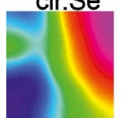

clr.Fe
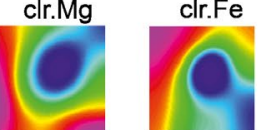

clr.Ca

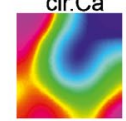

Palokas

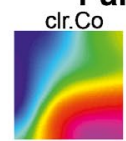

clr.As

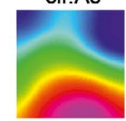

clr.Ni

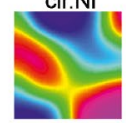

clr.Mg

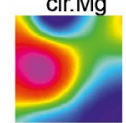

clr.Ca

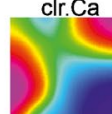

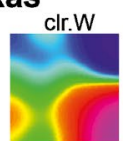

clr.Mo

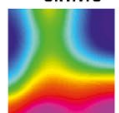

clr.Se
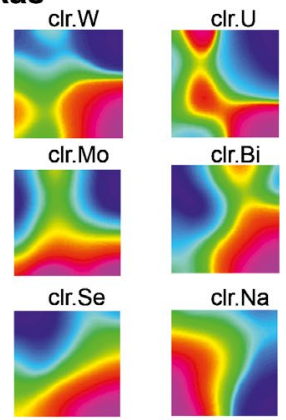

clr. Na

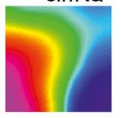

clr. Zn
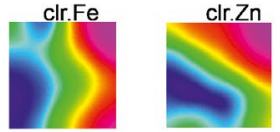

Figure 15. SOM component planes. Colors toward red-violet correspond to higher weight regions in the component planes. 

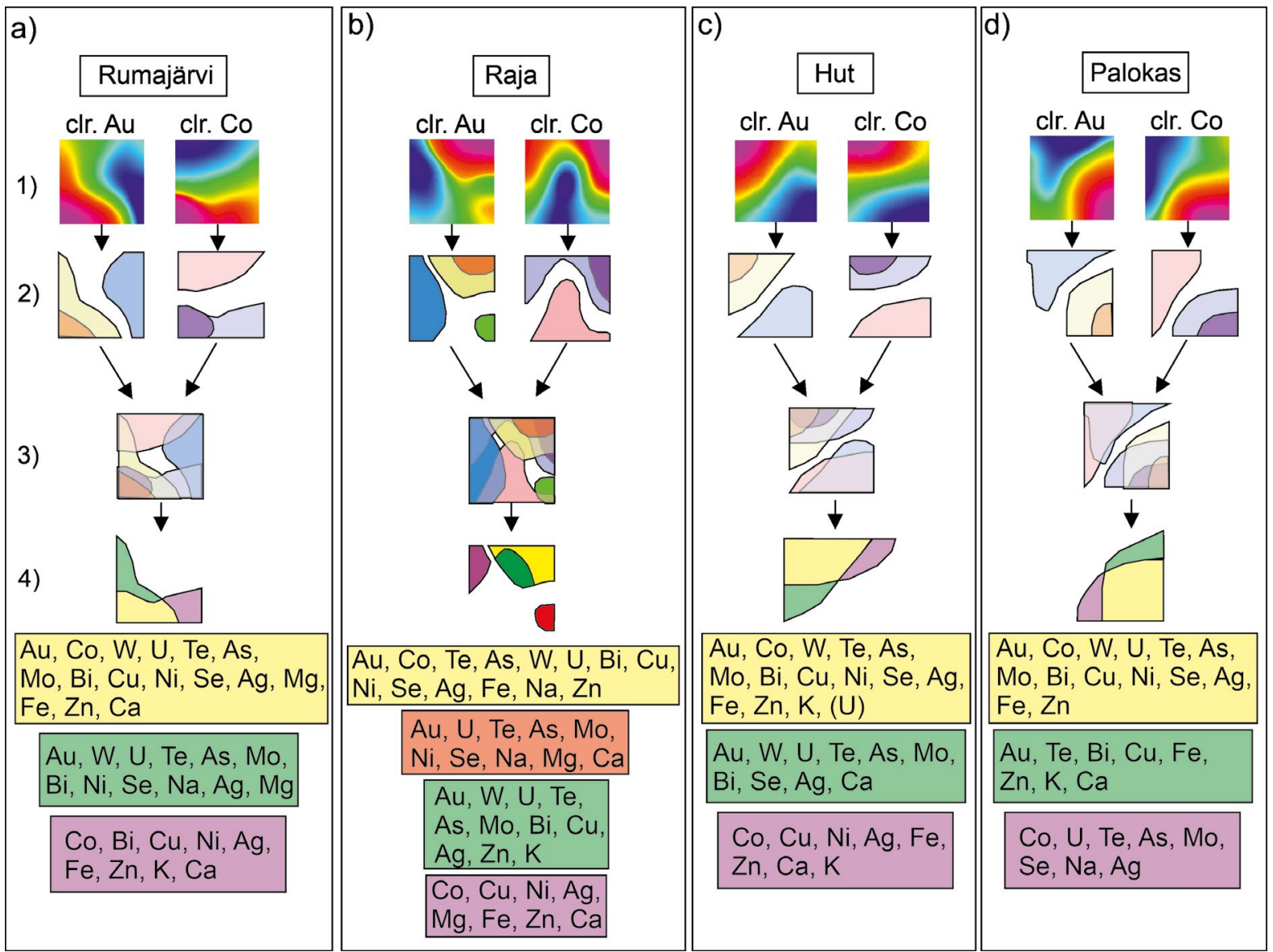

Figure 16. Investigation of component planes from each area to study domains of correlating elements with focus of $\mathrm{Au}$ and Co. Numbers on the left side of the figure indicate workflow as follows: 1) Investigation of individual component planes, 2) extracting the high and low weight domains from Au and Co component planes, 3) overlaying the domains and extracting domains based on the overlapping features, 4) overlaying the domains with other component planes to see overlaps indicating correlation.

\section{Discussion}

Knowledge of the textural location and association of the valuable minerals within mineral deposit is crucial for determining the formation history, but also for optimizing the mineral processing workflow. Especially in multiphase mineral deposits, different textural settings can give indications of their complex history. Fig. 18 shows summarized and simplified gold textural associations based on SEM-AM mapping of gold grains from the different deposits within the Rajapalot area. Despite the variation in the lithology and mineralogy, gold seems to follow similar type of textural location in all studied samples, as inclusions within silicates or sulfides, fractures in silicates, silicate-silicate grain boundaries, silicate-sulfide grain boundaries or silicate-oxide grains boundaries. However, the association of gold with the Co-bearing phases shows differences between the deposits. Gold is found to be within the cobaltite in the Palokas deposit. In Rumajärvi, gold is locally associated but not with direct contact with linnaeite. In Hut, no Co-minerals were found from the studied samples. This can be however, result of the sampling bias and further sampling would most probably reveal $\mathrm{Au}-\mathrm{Co}$ association from the Hut as well. In the studied samples from Raja, gold shows close 
a)
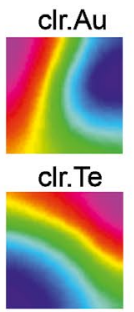

clr.Cu

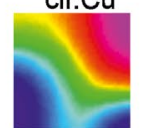

clr.Ag

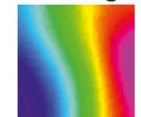

clr.K

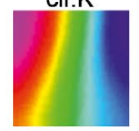

c)

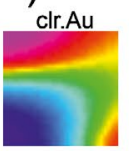

clr.Te

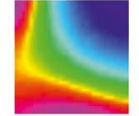

clr.Cu

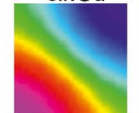

clr.Ag

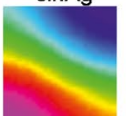

clr.Ca

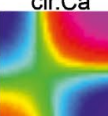

Rumajärvi

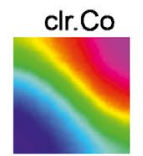

clr.As

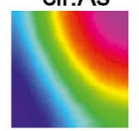

clr.Ni

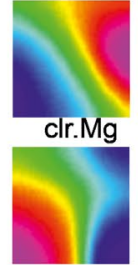

clr.Ca
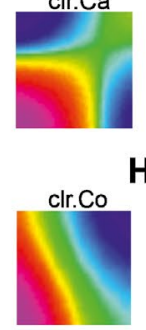

clr.As

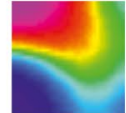

clr.Ni

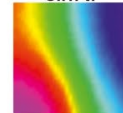

clr.Mg

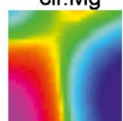

clr.K

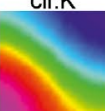

Hut b)
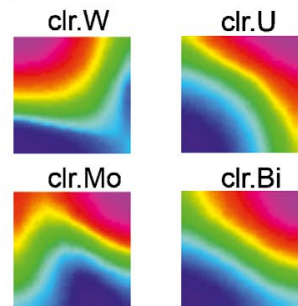

clr. Na

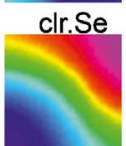

clr.Fe
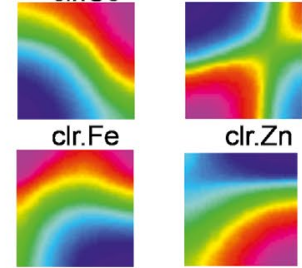

clr.Mo

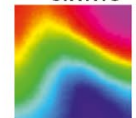

r.Bi

clr.Zn
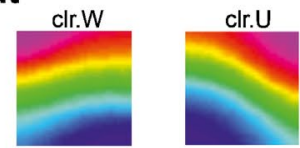

clr.Bi
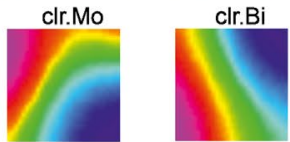

clr.Se

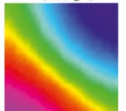

clr. $\mathrm{Na}$

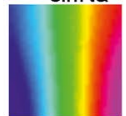

$\mathrm{clr} . \mathrm{Fe}$

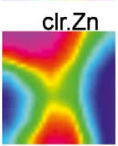

d)

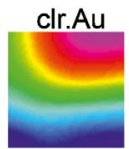

clr.Te

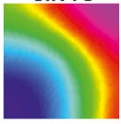

clr.Cu

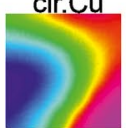

clr.Ag
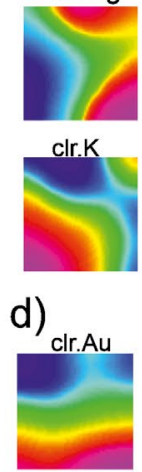

clr.Te
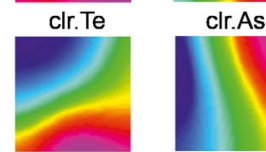

clr.As

Palokas

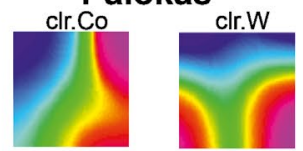

clr.Mo

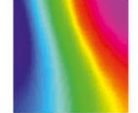

clr.Ni
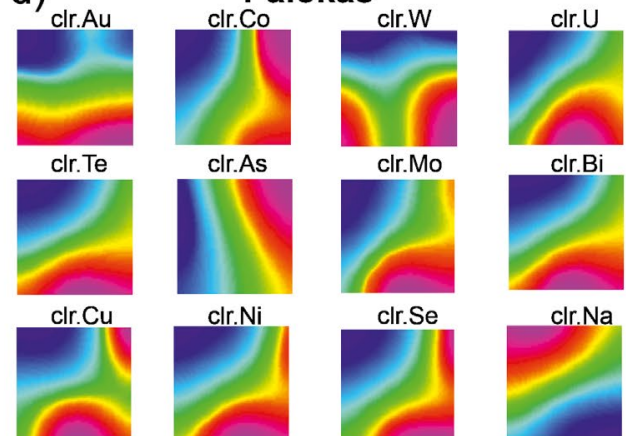

clr.Bi
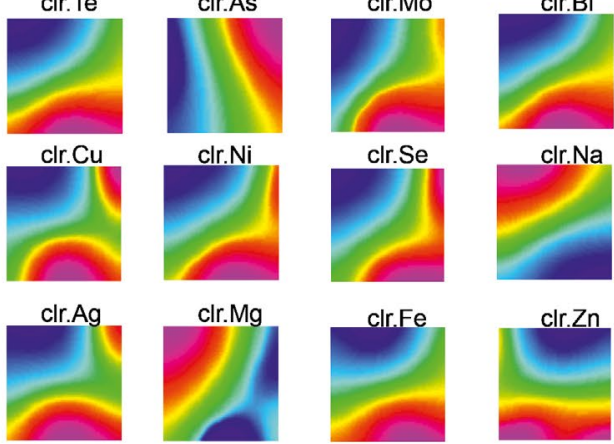

clr.K
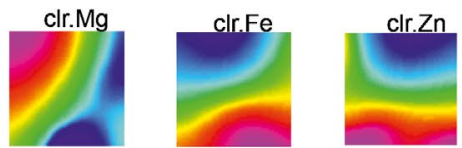

Figure 17. SOM component planes for samples with Au over $0.1 \mathrm{~g} / \mathrm{t}$. Colors toward red-violet correspond to higher weight regions in the component planes.

association with molybdenite which is resembled in geochemistry (correlation of Au and Mo) from all the studied areas. Mo show high weight region in areas not correlating gold where U-Mo association is inferred. This reflects the multigenerational history of Mo in the area as well, with published
Re-Os ages of > $2.0 \mathrm{Ga}$ coinciding with the primary U mineralization at Rompas-Rajapalot and Kivilompolo Mo mineralization (Molnár et al. 2016, 2017; Ranta et al. 2020). In Palokas, close association of gold and molybdenite are reported (Molnár et al. 2017; Ranta et al. 2018), which 


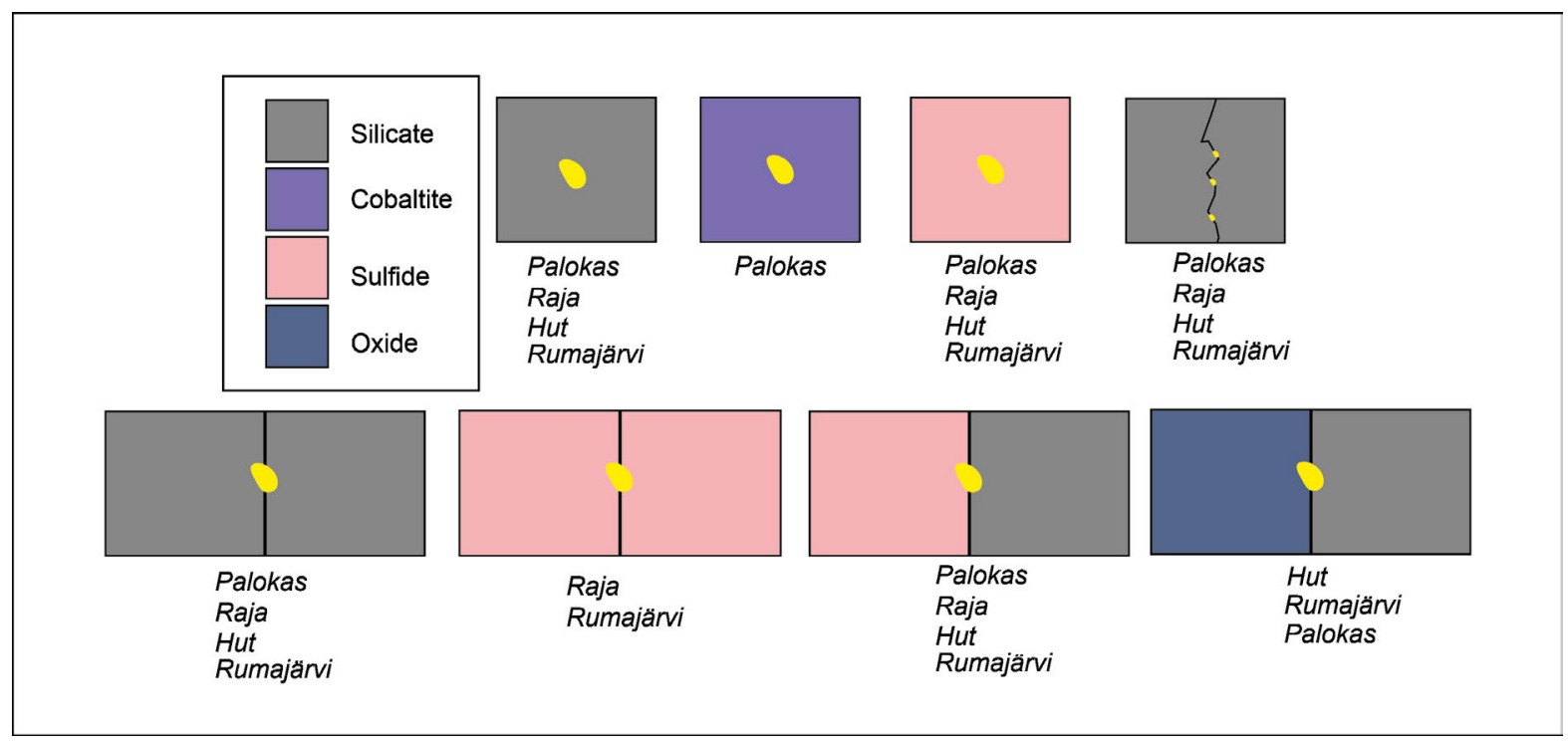

Figure 18. Simplified textural associations of gold within the Rajapalot area.

showed Re-Os age of ca. 1.78 Ga (Molnár et al. 2017) corresponding to the Mo-Au correlations in the SOM component planes (Fig. 15-17).

The strong correlation between $\mathrm{Au}-\mathrm{Te}-\mathrm{Bi}$ is seen in the SOM maps. In terms of mineral association, this association is shown in the samples with close association of native gold and Bi-tellurides, often intergrown with each other. Tungsten is correlated with the gold in the SOM maps. Correlations reflect the spatial relationship of scheelite and gold in all target areas, identified commonly from the drill cores using UV-light. Potassium shows dominantly antithetic relationship to gold, although some overlaps are observable. In general, mineralization at Rajapalot shows broadly two different related alteration styles, Fe-Mg with abundant chlorite as characteristic retrograde alteration mineral, and $\mathrm{K}-\mathrm{Fe}$ alteration with sericite or biotite characterizing the alteration related to the mineralogy. Most of the potassium weights in SOM component plane most probably reflects the rock composition and thus the mineralization related alteration is masked in the geochemical dataset and shown only locally with weak correlation between the $\mathrm{K}$ and Au. Using combination of samples from all the targets with Au above $0.1 \mathrm{~g} / \mathrm{t}$, allows us to observe more closely to the alteration associations related to the Au. Correlation with $\mathrm{K}$ can be inferred clearly with Rumajärvi and Raja (Fig. 17a-b) which are characterized by $\mathrm{K}-\mathrm{Fe}$ alteration in drill core observations. Palokas on the other hand, is characterized more by $\mathrm{Fe}-\mathrm{Mg}$ alteration related to the gold mineralization which can be seen on the SOM component planes as lack of correlation between $\mathrm{Au}$ and K (Fig. 17d). This can be a result of chloritization of biotite during the retrograde alteration. Textural observations in this study support the early observations that gold represents a late phase, occurring for example in fractures of silicates and associated with the late sulfideoxide phases. Furthermore, the late gold is also represented in tourmaline-sulfide breccias (not sampled for this study), reported from Palokas in Ranta et al. (2018). SOM analyses shows that there are domains with different elemental associations, most interestingly, domains with $\mathrm{Au}-\mathrm{Co}, \mathrm{Au}-$ only and Co-only, possible indicating different mineralization stages or processes relating to the precipitation conditions/mechanisms such as the local composition differences of the host rocks (e.g. Au introduction to Co-rich host rock vs. Copoor host rock). Farajewicz (2018) concluded 
that based on the appearance of cobaltite within the matrix of albite clasts, strongly associated with the phase of albitization, cobaltite is relatively early, formed before the main deformation events. The textural location of cobaltite in this study are similar to Farajewicz (2018). Behavior of cobalt and gold in hydrothermal system are not similar. In general in orogenic settings, gold is carried by sulfur complexes in relatively reduced and low-salinity fluids produced during metamorphic devolatilization (e.g. Patten et al. 2020). Experimental studies regarding the behavior of cobalt in hydrothermal solutions show that in low-temperatures $\left(<200{ }^{\circ} \mathrm{C}\right)$, the $\mathrm{CoHS}^{+}$is the dominant dissolved form of cobalt in solutions whereas in higher temperatures $\mathrm{CoCl}_{4}^{2-}$ dominates (Migdisov et al. 2011). Ranta et al. (2018) showed that the formation of late gold in Rajapalot formed in approximately $300{ }^{\circ} \mathrm{C}$, based on the fluid inclusion microthermometry from the Au-related tourmaline. In these temperatures, the $\mathrm{Cl}^{-}$ligand is the dominant Co carrying complex. The fluid inclusion and tourmaline geochemistry indicates that the fluids were reduced and low-salinity, typical for carrying Au in sulfur complexes (Ranta et al. 2018). Thus, the textural and geochemical evidence for pointing different origin for $\mathrm{Au}$ and Co is supported by the fluid inclusion studies as well. Fluids with higher salinity is needed for explaining the enrichment of cobalt in the Rajapalot area. Evaporites are potential candidate for origin of the saline fluids which are capable of leaching and transporting base metals (including Co) and uranium that could explain the cobalt enrichment and primary uranium mineralization at the Rompas-Rajapalot area. Vasilopolous et al. (2021) studied the whole-rock geochemistry and sulfide geochemistry and S-isotopes along with B-isotope data of tourmaline from the Juomasuo Au-Co deposit in the Kuusamo belt. Their results showed mineralization events with Co-only, Au$\mathrm{Co}$ and Au-only stages with probable involvement of saline evaporitic related fluids. In this study, as one textural setting, gold was found within the albite matrix. Albite alteration is common in the
Paleoproterozoic volcano-sedimentary rocks and many mineral deposits are related to the albitized rocks (Cook \& Ashley 1992; Oliver et al. 2004; Melezhik et al. 2013, 2015). Albitization increases the competency of the rocks, resulting brittle behavior during deformation and allowing metalliferous fluids to percolate into the fracture network and precipitating metals and gangue minerals via boiling during the sudden pressure drop. Boiling was shown to be the most probable precipitation mechanism in the late sulfidetourmaline breccias in Palokas, based on the fluid inclusion studies of tourmaline (Ranta et al. 2018). In highly sericitized rocks, mineralization related sericitization would drive cause $\mathrm{pH}$ changes of the gold-bearing fluids, decreasing the solubility of the gold leading to the precipitation. The exact ages of the different mineralization stages cannot be evaluated at this stage. Based on the earlier studies, the late Au-only event is around $1.78 \mathrm{Ga}$ (e.g. Molnár et al. 2017; Ranta et al. 2017, 2018). If the evaporitic fluids are responsible for the mobilization of cobalt, it's enrichment could have initially been already in the pre-orogenic stage, during the rifting stage of the basin evolution. Primary uranium mineralization and molybdenum mineralization close to the Rompas-Rajapalot area is shown to be ca. 2 Ga old (Molnár et al. 2016, 2017; Ranta et al. 2020). The early fluids related to the evaporites would have suitable composition to mobilize cobalt along with uranium and molybdenum from oxidized hosts into overlying reduced traprocks. High salinity fluids can also be produced e.g. during the orogeny by interaction of evaporitic rocks during metamorphism (e.g. Yardley \& Graham 2002; Eglinger et al. 2014). Cobalt could have possible been initially enriched in sulfidic sea in evaporative margins and remobilized during the Svecofennian orogeny in similar way than it was suggested by Qiu et al. (2021) from Zhongtiao Mountains, Central China. The available geochronological data studies from Au-only and atypical gold deposits show similar mineralization peaks at $1.92-1.85 \mathrm{Ga}$, around the onset and peak metamorphic condition of the 
Svecofennian orogeny across the Paleoproterozoic belts and another peak at $<1.8 \mathrm{Ga}$, indicating long-lived re-activated structures (e.g. Molnár et al. 2018). Interestingly in the Rajapalot area, current understanding of the mineralized system shows no evidences of the syn-orogenic mineralization event, thus all evidence points toward the late to even post-orogenic timing. Whether this is only biased by the current understanding or true lack of the gold enrichment during syn-orogenic times, is at this time, not known. Future studies should focus on determining the trace-elemental and isotopic signature of different mineralization stages and possible dating of the mineralization using e.g. hydrothermal monazite or xenotime in order to describe mineralization stages in more detailed across the whole Rajapalot $\mathrm{Au}-\mathrm{Co}$ system.

\section{Conclusions}

SEM-AM techniques are powerful method of studying the textural settings of precious minerals and combined with the exploratory geochemical analysis using unsupervised machine learning methods, such as self-organizing maps, can reveal the hidden structures of the multidimensional geochemical datasets and therefore, helps to aid in the understanding of multi-event mineralized systems. In the Rajapalot area, gold shows textural settings that indicate late introduction of gold relative to the most other rock minerals. Enrichment of cobalt seem to be separate earlier event based on the textural evidence and whole-rock geochemical SOM. Overall, based on the SOM component planes, Co-only, Au-Co and Au-only stages can be inferred. Different mineralizationrelated alteration events are reflected especially in the SOM maps of filtered Au > 0.1 g/t (K-Fe vs. Mg$\mathrm{Fe})$ and the elemental association of gold inferred from the whole-rock geochemical dataset using SOM can be effectively verified with the textural observations of gold using SEM based automated mineralogy methods.

\section{Acknowledgements}

Mawson $\mathrm{Oy}$ is thanked for providing the geochemical dataset and access to the drill cores. This project was funded by K.H. Renlund Foundation. Two reviewers, Dr. Antonin Richard and Dr. Muhammad Sayab are thanked for their constructive comments which significantly improved the quality of the manuscript.

\section{Supplementary data}

Electronic Appendices A-C for this article are available via Bulletin of the Geological Society of Finland web page.

\section{References}

Aitchison, J. 1986. The statistical analysis of compositional data. Chapman \& Hall, New York, 416 p.

Bachmann, K., Frenzel, M., Krause, J. \& Gutzmer, J., 2017, Advanced Identification and Quantification of InBearing Minerals by Scanning Electron MicroscopeBased Image Analysis: Microscopy and Microanalysis 23, no. 3, p. 527-537. https://doi.org/10.1017/S1431927617000460.

Cook, N. D. J. \& Ashley, P. M., 1992. Meta-evaporite sequence, exhalative chemical sediments and associated rocks in the Proterozoic Willyama Supergroup, South Australia: Implications for metallogenesis. Precambrian Research 56, 211-226.

https://doi.org/10.1016/0301-9268(92)90102-T

Cook, N., Molnár, M., O’Brien, H., Lahaye, Y. \& Tapio, J., 2019. The evolution of the Peräpohja belt as viewed from within the Rompas-Rajapalot project. In: Cook N. (ed.) NEXT - 3rd Progress Meeting 7-10 October, 2019, Pohtimolampi, Rovaniemi, Finland: Rovaniemi: Mawson Oy, p. 13-16.

Eglinger, A., Ferraina, C., Tarantola, A., Andre'-Mayer, A-S., Vanderhaeghe, O., Boiron, M-C., Dubessy, J., Richard, A. \& Brouand, M., 2014. Hypersaline fluids generated by high-grade metamorphism of evaporites: fluid inclusion study of uranium occurrences in the Western Zambian Copperbelt. Contribution to Mineralogy and Petrology 167: 967. https://doi.org/10.1007/s00410-014-0967-9

Eilu, P. 2015. Overview on gold deposits in Finland. In: Maier, W.D., O’Brien, H., Lahtinen, R. (eds.), Mineral Deposits of Finland, Elsevier, Amsterdam, pp. 377-403. https://doi.org/10.1016/B978-0-12-410438-9.00015-7 
Fandrich, R., Gu, Y., Burrows, D. \& Moeller, K., 2007, Modern SEM-based mineral liberation analysis: International Journal of Mineral Processing, v. 84, no. $1-4$, p. 310-320. https://doi.org/10.1016/j.minpro.2006.07.018.

Farajewich, M. 2018. Mineral relationships of cobaltite and cobalt pentlandite at Rajapalot, Finland. M.Sc. Thesis, University of Exeter, $85 \mathrm{p}$.

Goodall, W. R., Scales, P. J. \& Butcher, A. R., 2005. The use of QEMSCAN and diagnostic leaching in the characterization of visible gold in complex ores. Minerals Engineering 18, 877-886.

https://doi.org/10.1016/j.mineng.2005.01.018

Hanski, E. J. \& Melezhik, V. A., 2012. Litho- and chronostratigraphy of the Karelian formations. In: Melezhik, V. A., Prave, A. R., Hanski, E. J., Fallick, A. E., Lepland, A., Kump, L. R., Strauss, H. (Eds.), Reading the Archive of Earth's Oxygenation. Volume 1: The Palaeoproterozoic of Fennoscandia as Context for the Fennoscandian Arctic Russia - Drilling Early Earth Project. Springer-Verlag, Berlin/Heidelberg, pp. 39-110.

Huhma, H., Cliff, R. A., Perttunen, V. \& Sakko, M., 1990. Sm$\mathrm{Nd}$ and $\mathrm{Pb}$ isotopic study of mafic rocks associated with early Proterozoic continental rifting: the Peräpohja schist belt in northern Finland. Contributions to Mineralogy and Petrology, 104, p. 369-379. https://doi.org/10.1007/BF00321491

Iljina, M. \& Hanski, E., 2005. Layered mafic intrusions of the Tornio-Näränkävaara belt. In: Lehtinen, M., Nurmi, P. A., Rämö, O. T. (Eds.), Precambrian Geology of FinlandKey to the Evolution of the Fennoscandian Shield. Elsevier B.V, Amsterdam, pp. 101-138. https://doi.org/10.1016/S0166-2635(05)80004-0

Jafrasteh, B., Fathianpour, N. \& Suarez, A., 2018. Comparison of machine learning methods for copper grade estimation. Computer Geosciences 22, 1371-1388. https://doi. org/10.1007/s10596-018-9758-0

Kaplan, U. E. \& Topal, E., 2020. A new ore grade estimation using combine machine learning algorithms. Minerals 10, 847. https://doi.org/10.3390/min 10100847

Keulen, N., Malkki, S.N. \& Graham, S. 2019. Automated mineralogy applied to metamorphic rocks. Minerals 10, 47,29 p. https://doi.org/10.3390/min 10010047

Klose, C. D., 2006. Self-organizing maps for geoscientific data analysis: geological interpretation of multidimensional geophysical data. Computers \& Geosciences 10, 265277. https://doi.org/10.1007/s10596-006-9022-x

Kohonen, T., 2001. Self-organizing maps. Springer-Verlag Berlin Heidelberg, Germany, 502 p.

https://doi.org/ 10.1007/978-3-642-56927-2

Kyläkoski, M., Hanski, E. \& Huhma, H., 2012. The Petäjäskoski Formation, a new lithostratigraphic unit in the Paleoproterozoic Peräpohja Belt, northern Finland. Bulletin of the Geological Society of Finland 84, 85-120. https://doi.org/10.17741/bgsf/84.2.001
Köykkä, J., Lahtinen, R. \& Huhma, H., 2019. Provenance evolution of the Paleoproterozoic metasedimentary cover sequences in northern Fennoscandia: Age distribution, geochemistry, and zircon morphology. Precambrian research, $331,21 \mathrm{p}$. https://doi.org/10.1016/j.precamres.2019.105364

Lahtinen, R., Sayab, M. \& Karell, F., 2015. Near-orthogonal deformation successions in the poly-deformed Paleoproterozoic Martimo belt: implications for the tectonic evolution of Northern Fennoscandia. Precambrian Research, 270, p. 22-38. https://doi.org/10.1016/j.precamres.2015.09.003

Lahtinen, R., Huhma, H., Lauri, L. S. \& Sayab, M., 2019. Geochemical and $\mathrm{U}-\mathrm{Pb}$ and $\mathrm{Sm}-\mathrm{Nd}$ isotopic constraints on the evolution of the Paleoproterozoic Ylitornio nappe complex, northern Fennoscandia. Bulletin of the Geological Society of Finland, 91, p. 75-100.

https://doi.org/10.17741/bgsf/91.1.003

Melezhik, V. A., Medvedev, P. V. \& Svetov, S. A., 2013. The Onega basin. In: Melezhik, V. A., Prave, A. R., Hanski, E. J., Fallick, A. E., Lepland, A., Kump, L. R., Strauss, H. (eds.), Reading the Archive of Earth's Oxygenation, Volume 1, The Palaeoproterozoic of Fennoscandia as Context for the Fennoscandian Arctic Russia - Drilling Early Earth Project. Springer-Verlag, Berlin, Heidelberg, p. 387-490.

Melezhik, V. A., Bingen, B., Sandstad, J. S., Pokrovsky, B. G., Solli, A. \& Fallick, A. E., 2015. Sedimentary-volcanic successions of the Alta-Kvaenangen Tectonic Window in the northern Norwegian Caledonides: Multiple constraints on deposition and correlation with complexes on the Fennoscandian Shield. Norwegian Journal of Geology 95, 245-284. http://dx.doi.org/10.17850/njg95-3-01

Migdisov, A. A, Zezin, D. \& Williams-Jones, A. E., 2011. An experimental study of cobalt (II) complexation in $\mathrm{Cl}^{-}$and H2S-bearing hydrothermal solutions. Geochimica et Cosmochimica Acta 75, 4065-4079.

https://doi.org/10.1016/j.gca.2011.05.003

Molnár, F. 2019. Cobalt in orogenic gold mineral systems of northern Fennoscandia. In: Cook N. (eds.), NEXT - 3rd Progress Meeting 7-10 October, 2019, Pohtimolampi, Rovaniemi, Finland: Rovaniemi: Mawson Oy, pp. 11-12.

Molnár, F., Oduro, H. Cook, N. D. J., Pohjolainen, E., Takács, Á., O’Brien, H., Pakkanen, L., Johanson, B. \& Wirth, R., 2016. Association of gold with uraninite and pyrobitumen in the metavolcanic rock hosted hydrothermal Au-U mineralisation at Rompas, Peräpohja Schist Belt, northern Finland. Mineralium Deposita, 51, 681-702. https://doi.org/10.1007/s00126-015-0636-6

Molnár, F., O’Brien, H., Stein, H. \& Cook, N. D. J., 2017. Geochronology of Hydrothermal Processes Leading to the Formation of the $\mathrm{Au}-\mathrm{U}$ Mineralization at the Rompas Prospect, Peräpohja Belt, Northern Finland: Application of Paired U-Pb Dating of Uraninite and Re-Os Dating of Molybdenite to the Identification 
of Multiple Hydrothermal Events in a Metamorphic Terrane. Minerals, 7 (9), 23 p. https://doi.org/10.3390/min7090171

Molnár, F., Middleton, A., Stein, H., O’Brien, H., Lahaye, Y., Huhma, H., Pakkanen, L. \& Johanson, B., 2018. Repeated syn- an post-orogenic gold mineralization events between 1.92 and $1.76 \mathrm{Ga}$ along the Kiistala Shear Zone in the Central Lapland Greenstone Belt, northern Finland. Ore Geology Reviews 101, 936-959. https://doi.org/10.1016/j.oregeorev.2018.08.015

Oliver, N. H. S., Cleverley, J. S., Mark, G., Pollard, P. J., Fu, B., Marshall, L. J., Rubenach, M. J., Williams, P.J. \& Baker, T., 2004. Modeling the role of sodic alteration in the genesis of iron-oxide-copper-gold deposits, eastern Mount Isa block, Australia. Economic Geology 99, 1145-1176. https://doi.org/10.2113/gsecongeo.99.6.1145

Patten, C. G. C., Pitcairn, I. K., Molnár, F., Kolb, J., Beaudoin, C., Guilmette, C. \& Peillod, A., 2020. Gold mobilization during metamorphic devolatilization of Archean and Paleoproterozoic metavolcanic rocks. Geology 48, 11101114. https://doi.org/10.1130/G47658.1

Perttunen, V. \& Vaasjoki, M., 2001. U-Pb geochronology of the Peräpohja Schist Belt, northwestern Finland. Bulleting of the Geological Society of Finland, 33, p. 4584.

Perttunen, V., Hanski, E. \& Väänänen, J., 1995. Stratigraphical map of the Peräpohja Schist Belt. In: 22nd Nordic Geological Winter Meeting, January 8-11, 1996s, Turku, Abstracts, p. 152.

Piippo, S., Skyttä, P. \& Kloppenburg, A., 2019. Linkage of crustal deformation between the Archean basement and the Proterozoic cover in the Peräpohja area, northern Fennoscandia. Precambrian Research 324, 285-302. https://doi.org/10.1016/j.precamres.2019.02.003

Qiu, Z-J., Fan, H-R., Goldfarb, R., Tomkins, A.G., Yang, K-F, Li, X-C., Xie, L-W. \& Liu, X., 2021. Cobalt concentration in a sulfidic sea and mobilization during orogenesis: Implications for targeting epigenetic sediment-hosted $\mathrm{Cu}-\mathrm{Co}$ deposits. Geochimica et Cosmochimica Acta 305, 1-18. https://doi.org/10.1016/j.gca.2021.05.001

Ranta, J.-P., Lauri, L.S., Hanski, E., Huhma, H., Lahaye, Y. \& Vanhanen, E., 2015. U-Pb and Sm-Nd isotopic constraints on the evolution of the Paleoproterozoic Peräpohja Belt, northern Finland. Precambrian Research, 266, p. 246-259.

https://doi.org/10.1016/j.precamres.2015.05.018

Ranta, J.-P., Hanski, E., Cook, N. \& Lahaye, Y., 2017. Source of boron in the Palokas gold deposit, northern Finland: Evidence from boron isotopes and major element composition of tourmaline. Mineralium Deposita 52, 733-746. https://doi.org/10.1007/s00126-016-0700-x
Ranta, J.-P., Molnár, F., Hanski, E. \& Cook, N., 2018. Epigenetic gold occurrence in a Paleoproterozoic meta-evaporitic sequence in the Rompas-Rajapalot $\mathrm{Au}$ system, Peräpohja belt, northern Finland. Bulletin of the Geological Society of Finland 90, 69-108. https://doi.org/10.17741/bgsf/90.1.004

Ranta, J-P., Hanski, E., Stein, H., Goode, M., Mäki, T. \& Taivalkoski, A., 2020. Kivilompolo Mo mineralization in the Peräpohja belt revisited: Trace element geochemistry and Re-Os dating of molybdenite. Bulleting of the Geological Society of Finland 92 (2), 131-150. https://doi.org/10.17741/bgsf/92.2.004

Sayab, M., Suuronen, J-P., Molnár, F., Villanova, J., Kallonen, A., O’Brien, H., Lahtinen, R. \& Lehtonen, M., 2016. Three-dimensional textural and quantitative analyses of orogenic gold at the nanoscale. Geology 44, 739-742. https://doi.org/10.1130/G38074.1

Schulz, B., 2020. Editorial for special issue "Application of SEM automated mineralogy: From ore deposits over processing to secondary resource characterization". Minerals 10(12), 1103, 1-5. https://doi.org/ 10.3390/min 10121103

Tainio, J. 2014. Rovaniemen kunnassa sijaitsevien Vanttauksen, Lehmikarin ja Äijävaaran appiniitti-intruusioiden petrografian ja geokemian tutkimus. Master's thesis, Department of Geosciences and Geography, University of Helsinki, 93 p.

Thió-Fernández, S. \& Martín-Fernández, J. A., 2006. Detailed guide to CoDaPack: A freeware compositional software. Geological Society of London Special Publication 264(1), 101-118. https://doi.org/10.1144/GSL.SP.2006.264.01.08

Vanhanen, E., Cook, N. D. J., Hudson, M. R., Dahlenborg, L., Ranta, J. P., Havela, T., Kinnunen, J., Molnár, F., Prave, A. R. \& Oliver, N. H. S., 2015. Rompas prospect, Peräpohja Schist Belt, northern Finland. In: Maier, W. D., O’Brien, H. \& Lahtinen, R (eds.), Mineral Deposits of Finland. Elsevier, Amsterdam, pp. 467-484.

Vasilopoulos M., Molnár, F., O’Brien, H., Lahaye, Y., Lefebvre, M., Richard, A., André-Mayer, A-S., Ranta, J-P. \& Talikka, M., 2021. Geochemical signatures of mineralizing events in the Juomasuo Au-Co deposit, Kuusamo belt, northeastern Finland. Mineralium Deposita. https://doi.org/10.1007/s00126-020-01039-8

Vesanto, J., Himberg, J., Alhoniemi, E. \& Parhankangas, J., 2000. SOM toolbox for Matlab 5. University of Helsinki, report $A 57,60 \mathrm{p}$.

Yardley, B. W. D. \& Graham, J. T., 2002. Origins of salinity in metamorphic fluids. Geofluids 2, 249-256. https://doi.org/10.1046/j.1468-8123.2002.00042.x 